\title{
Structural and (Pseudo-)Enzymatic Properties of Neuroglobin: Its Possible Role in Neuroprotection
}

\author{
Giovanna De Simone ${ }^{1,+}+$ , Diego Sbardella ${ }^{2, \dagger}$, Francesco Oddone ${ }^{2}$, Alessandra Pesce ${ }^{3}$, Massimo Coletta ${ }^{2,4, *}$ \\ and Paolo Ascenzi 1,5,6,*(D) \\ 1 Dipartimento di Scienze, Università Roma Tre, Viale Marconi 446, 00146 Roma, Italy; \\ giovanna.desimone@uniroma3.it \\ 2 IRCCS Fondazione Bietti, 00198 Roma, Italy; diego.sbardella@fondazionebietti.it (D.S.); \\ francesco.oddone@fondazionebietti.it (F.O.) \\ 3 Dipartimento di Fisica, Università di Genova, Via Dodecaneso 33, 16100 Genova, Italy; pesce@fisica.unige.it \\ 4 Dipartmento di Scienze Cliniche e Medicina Traslazionale, Università di Roma "Tor Vergata", \\ Via Montpellier 1, 00133 Roma, Italy \\ 5 Accademia Nazionale dei Lincei, Via della Lungara 10, 00165 Roma, Italy \\ 6 Unità di Neuroendocrinologia, Metabolismo e Neurofarmacologia, IRCSS Fondazione Santa Lucia, \\ 00179 Roma, Italy \\ * Correspondence: coletta@med.uniroma2.it (M.C.); ascenzi@uniroma3.it (P.A.); \\ Tel.: +39-06-72596365 (M.C.); +39-06-57336321 (P.A.) \\ + These authors contributed equally to this study.
}

check for updates

Citation: De Simone, G.; Sbardella, D.; Oddone, F.; Pesce, A.; Coletta, M.; Ascenzi, P. Structural and (Pseudo-)Enzymatic Properties of Neuroglobin: Its Possible Role in Neuroprotection. Cells 2021, 10, 3366. https://doi.org/10.3390/ cells10123366

Academic Editors: Roberta Misasi,

Maria Marino and

Margherita Ruoppolo

Received: 18 October 2021

Accepted: 23 November 2021

Published: 30 November 2021

Publisher's Note: MDPI stays neutral with regard to jurisdictional claims in published maps and institutional affiliations.

Copyright: (c) 2021 by the authors. Licensee MDPI, Basel, Switzerland. This article is an open access article distributed under the terms and conditions of the Creative Commons Attribution (CC BY) license (https:// creativecommons.org/licenses/by/ $4.0 /)$.

\begin{abstract}
Neuroglobin (Ngb), the third member of the globin family, was discovered in human and murine brains in 2000. This monomeric globin is structurally similar to myoglobin (Mb) and hemoglobin $(\mathrm{Hb}) \alpha$ and $\beta$ subunits, but it hosts a bis-histidyl six-coordinated heme-Fe atom. Therefore, the heme-based reactivity of Ngb is modulated by the dissociation of the distal HisE7-hemeFe bond, which reflects in turn the redox state of the cell. The high Ngb levels $(\sim 100-200 \mu \mathrm{M})$ present in the retinal ganglion cell layer and in the optic nerve facilitate the $\mathrm{O}_{2}$ buffer and delivery. In contrast, the very low levels of $\mathrm{Ngb}(\sim 1 \mu \mathrm{M})$ in most tissues and organs support (pseudo-)enzymatic properties including $\mathrm{NO} / \mathrm{O}_{2}$ metabolism, peroxynitrite and free radical scavenging, nitrite, hydroxylamine, hydrogen sulfide reduction, and the nitration of aromatic compounds. Here, structural and (pseudo-)enzymatic properties of $\mathrm{Ngb}$, which are at the root of tissue and organ protection, are reviewed, envisaging a possible role in the protection from neuronal degeneration of the retina and the optic nerve.
\end{abstract}

Keywords: neuroglobin; structure; reactivity; (pseudo-)enzymatic properties; neuroprotection; retina

\section{Introduction}

Mammalian tetrameric hemoglobin $(\mathrm{Hb})$ and monomeric myoglobin $(\mathrm{Mb})$ are generally taken as macromolecular models, having been among the first proteins that were characterized from the structural and functional viewpoints. Over the last 30 years, the increase of genomic information and the availability of expression systems opened new horizons in the distribution, folding, and function of all $\alpha$-helical globins [1-8].

All $\alpha$-helical globins are expressed in all living organisms, with putative globin genes occurring in many prokaryotes and eukaryotes. In prokaryotes, about $65 \%$ of the known bacterial genomes contain one or more globin gene, whereas globin genes have been found in the genome of more than $90 \%$ of the eukaryote organisms classified so far [9-13]. In addition to classical $3 / 3$ all $\alpha$-helical $\mathrm{Hb}$ and $\mathrm{Mb}$, several $3 / 3$ and $2 / 2 \alpha$-helical globins have been discovered over the last two decades in vertebrates: (i) neuroglobin $(\mathrm{Ngb})$ in neurons and glial cells, (ii) cytoglobin (Cygb) in fibroblasts, (iii) globin E (GbE) in avian eyes, $(i v)$ globin $\mathrm{X}(\mathrm{GbX})$ in many metazoans but not in birds and mammals, $(v)$ globin $\mathrm{Y}(\mathrm{GbY})$ in amphibians and monotreme mammals, and (vi) the chimeric heme-protein 
androglobin (Adgb) [8,10-20]. In humans, Adgb, Cygb, $\mathrm{Hb}, \mathrm{Mb}$, and $\mathrm{Ngb}$ are expressed in canonical and non-canonical sites fulfilling organ-specific (un)common functions [13].

In $3 / 3$ all $\alpha$-helical globins, present in unicellular and multicellular organisms, the heme is sandwiched between A-B-E $\alpha$-helices on one side and F-G-H $\alpha$-helices on the other side, with the proximal HisF8 residue forming the fifth coordination bond of the heme-Fe atom $[2,4,8]$. Only in unicellular organisms, all $\alpha$-helical globins characterized by the $2 / 2$-fold representing a subset of the $3 / 3 \alpha$-helical classical globin fold have been discovered $[6,21]$. Instead of the six to eight $\alpha$-helical segments (lettered A to $\mathrm{H}$ ) observed in the $3 / 3$ structural organization, the $2 / 2$ globin fold is composed of four $\alpha$-helices (named B, E, G, and H), which are arranged around the heme in a sort of bundle composed of the antiparallel pairs $\mathrm{B} / \mathrm{E}$ and $\mathrm{G} / \mathrm{H}$ connected by an extended polypeptide loop. The most striking differences between the $2 / 2$ and the $3 / 3$ globin folds are: (i) the drastically shortened or absent A-helix, (ii) the alteration of the C-E region, and (iii) the presence of a long polypeptide segment, which precedes the short $\alpha$-helix F where the proximal HisF8 residue is located coordinating the heme-Fe atom $[2,4,7,8,21]$. Over the last two decades, all $\beta$-barrel non-canonical globins (i.e., nitrophorins and nitrobindins) mainly devoted to NO metabolism have been reported [22-29]. Of note, human nitrobindin, corresponding to the $C$-terminal domain of the nuclear protein THAP4, has been hypothesized to act as a NO sensor modulating the transcriptional activity residing at the $N$-terminus [25-29].

Interestingly, cavities and/or tunnels within the protein matrix have been recognized in several members of all $\alpha$-helical and all $\beta$-barrel globins [25,30-38]. Although internal cavity/tunnel systems reduce the stability of globins, they play a pivotal role in controlling the diffusion of ligands and possibly substrates to the metal center and the reshaping of the heme pocket [39-41].

Beyond the well-known $\mathrm{O}_{2}$ transport and storage in Metazoa, globins have been reported to display (pseudo-)enzymatic properties including $\mathrm{NO} / \mathrm{O}_{2}$ metabolism, gas sensing, peroxidase activity, signaling functions, oxidative stress protection, fatty acid metabolism, anti-apoptotic effects, anti-proliferative and cytoprotective effects in cancer cells, anti-microbial and anti-inflammatory functions, and tissue repair and regeneration [8,10-13]. Here, the structural and (pseudo-)enzymatic properties of multifaced Ngb along with the possible protective role in the retina and the optic nerve are reviewed [13,42-49].

\section{The Ngb Structure}

Only the three-dimensional structures of Homo sapiens, Mus musculus, and Symsagittifera roscoffensis $\mathrm{Ngb}$ have been solved. Ngbs from the marine flat worm and mammals display the classical 3/3 globin fold, hosting the heme-group with $\alpha$-helices $\mathrm{A}, \mathrm{B}, \mathrm{E}, \mathrm{F}$, $\mathrm{G}$, and $\mathrm{H}$, which are organized into a two-layer structure (A-B-E and F-G-H) $[32,34,50]$ superimposable to that of $\mathrm{Mb}$ and $\mathrm{Hb}$ chains $[2,4,8,51]$. In ligand-free human and murine $\mathrm{Ngb}$, the heme-Fe atom is six-coordinated by four $\mathrm{N}$ atoms belonging to the heme plane; the proximal (or fifth) and the distal (or sixth) ligands of the metal center are HisF8 and HisE7 residues, respectively [32,34]. In human and murine Ngb, the HisE7 imidazole ring is staggered relative to the heme pyrrole $\mathrm{N}$ atoms, being oriented toward the methinic bridge $\mathrm{CHA}$ and $\mathrm{CHC}$ atoms of the porphyrin ring. As a result, hexa-coordination is facilitated, since the $\alpha$-helix E is pulled toward the heme by about $3.0 \AA$, relative to sperm whale $\mathrm{Mb}$, which instead displays a five-coordinated heme-Fe atom [2,32,34] (Figure 1A).

The heme distal site of human and murine $\mathrm{Ngb}$ is crowded by the apolar residues (PheB10, PheCD1, and ValE11) trapping the porphyrin ring. LysE10 participates as well to the stabilization of macrocycles by electrostatic interactions with heme propionates [32,34]. Both in the crystalline state and in solution, the heme of mutant human and murine ferric $\mathrm{Ngb}(\mathrm{Ngb}(\mathrm{III}))$ is accommodated in its pocket in two different geometries being rotated by $180^{\circ}$ about the $\alpha-\gamma$-meso axis [32,34]. The equilibrium constant for the two heme orientations in murine $\mathrm{Ngb}$ changes from 2:1 in ligand-free $\mathrm{Ngb}$ (III) to $\sim 1: 1$ in the $\mathrm{Ngb}$ (III)-cyanide complex, suggesting a role in the modulation of heme reactivity [52]. However, the structure of wild-type human Ngb reveals neither the occurrence of the heme 
isomerization nor the presence of multiple conformations of HisE7 [53]. Of note, the HisE7 and HisF8 imidazole rings of murine $\mathrm{Ngb}(\mathrm{III})$ show different orientations in the crystalline state and in solution, reflecting either the high exposure of the heme group to the bulk solvent or the absence of hydrogen-bond acceptors for the His NH protons provided by the heme-protein [54] (Figure 1B).

The overall fold of Symsagittifera roscoffensis Ngb1 matches well to that of murine ferrous carbonylated Ngb $[35,50]$. However, TrpCD3 is hydrogen bonded to one of the heme propionates and may represent a barrier for ligand access to the heme pocket. In addition, a water molecule is hydrogen-bonded to the heme distal HisE7 residue and to the second propionate of the heme group [50]. Unlike most globins, Symsagittifera roscoffensis $\mathrm{Ngb}$ displays a unique feature in that the $\alpha$-helix $\mathrm{F}$ is bent by the presence of ProEF10, possibly reflecting the heme-protein flexibility [50].

A large cavity/tunnel system, encompassing part of the heme distal and proximal sites, is present in the protein matrix of human and murine $\mathrm{Ngb}$, representing a pivotal determinant for the function and dynamics of these globins. In wild-type human Ngb, the cavity/tunnel system is shielded from the bulk solvent and is lined with hydrophobic residues, including ValE14, IleE15, ValG8, LeuG12, LeuH11, and ValH15. The volume of this cavity is $89 \AA^{3}$ and $225 \AA^{3}$ in molecules $A$ and B present in the asymmetric unit, respectively. The different cavity size observed in A and B monomers of wild-type human $\mathrm{Ngb}$ is not a crystallographic packing artifact but reflects the high flexibility of the CD region that is crucial in the modulation of the heme reactivity and in the reshaping of the internal cavities [53]. In addition, a solvent-inaccessible internal cavity connected to the heme distal pocket $\left(\sim 60 \AA^{3}\right)$ occurs in the neighborhood of the CD loop/ $\alpha$-helix D region [53]. In the ligand-free CysCD5Gly/CysD5Ser/CysG19Ser mutant of human Ngb, a protein cavity $\left(\sim 120 \AA^{3}\right)$ connects the heme distal pocket to the EF inter-helical hinge. This cavity is lined with hydrophobic residues provided by the $B, E, G$, and $\mathrm{H} \alpha$-helices. Although in the crystals the cavity appears to be shielded from the external solvent, the intramolecular contacts indicate that, in a dynamic context, solvent access may be gained through side chain fluctuations [32]. In the ligand-free CysD5Ser/CysG19Ser mutant of murine Ngb, two small cavities $\left(16 \AA^{3}\right.$ and $\left.11 \AA^{3}\right)$, are present on the heme distal side. Moreover, a highly hydrophobic cavity $\left(287 \AA^{3}\right)$, responsible for the unique CO binding mode $[34,35]$, connects the heme distal and proximal sides [34], being also connected with the external solvent through a channel. In fact, upon $\mathrm{CO}$ binding, heme slides towards the interior of the protein matrix, decreasing the structural disorder especially in the EF-F-FG region, and inducing peripheral structural changes, which may affect Ngb actions and partner recognition. The repositioning of the heme-Fe group affects the geometry of HisF8, always bound to the heme-Fe(II) atom, and of the PheG5 [35]. The unusual CO-dependent repositioning of the heme group avoids the necessity of a large HisE7 swinging motion to permit ligand entry in and exit from the heme distal pocket [35], which is instead observed in $\mathrm{Mb}$ and $\mathrm{Hb}$ (i.e., the so-called "E7 gate" mechanism) [55-57]. Although the orifice of the channel is narrow, diatomic ligands can nonetheless access the metal center by virtue of the flexibility of the EF corner contributing to the channel external wall [34,35,58-60]. Due to the larger internal packing defects and the more pronounced active site fluctuations, the $\mathrm{CO}$ transfer barriers are considerably lower in $\mathrm{Ngb}$ (II) as compared to $\mathrm{Mb}$ (II) [61-66] (Figure 1).

In ferrous carbonylated murine $\mathrm{Ngb}$, the $\mathrm{CO}$ molecule is bound to the heme-Fe(II) atom in a bent configuration, the Fe-C-O angle ranging between 100 and $156^{\circ}$ and the $\mathrm{Fe}-\mathrm{C}$ and $\mathrm{Fe}-\mathrm{O}$ distances range between 1.8 to $2.0 \AA$ and 2.5 to $3.0 \AA$, respectively. Moreover, the $\mathrm{O}$ atom of $\mathrm{CO}$ is placed at 2.8-3.2 $\AA$ from the NE atom of HisE7, possibly being stabilized by hydrogen bonding $[35,58,60,67]$.

In ferrous oxygenated Symsagittifera roscoffensis $\mathrm{Ngb1}, \mathrm{O}_{2}$ is bound to the distal site of the heme-Fe atom in a bent configuration, the Fe-O1-O2 angle being $136^{\circ}$. Moreover, the $\mathrm{Fe}-\mathrm{O} 1$ and $\mathrm{Fe}-\mathrm{O} 2$ distances are 1.96 and $3.05 \AA$, respectively, and the $\mathrm{O} 1$ and $\mathrm{O} 2$ atoms of 
$\mathrm{O}_{2}$ are located at 3.00 and $3.25 \AA$, respectively, from the NE atom of HisE7, which in turn stabilizes the heme-Fe-bound $\mathrm{O}_{2}$ by hydrogen bonding [50].

Mutagenesis on the structure of human and murine Ngb was relevant to understand at the atomic level the reactivity properties of this monomeric globin and to highlight the potential in vivo role of the redox modulation of the CD5-D5 disulfide bond.
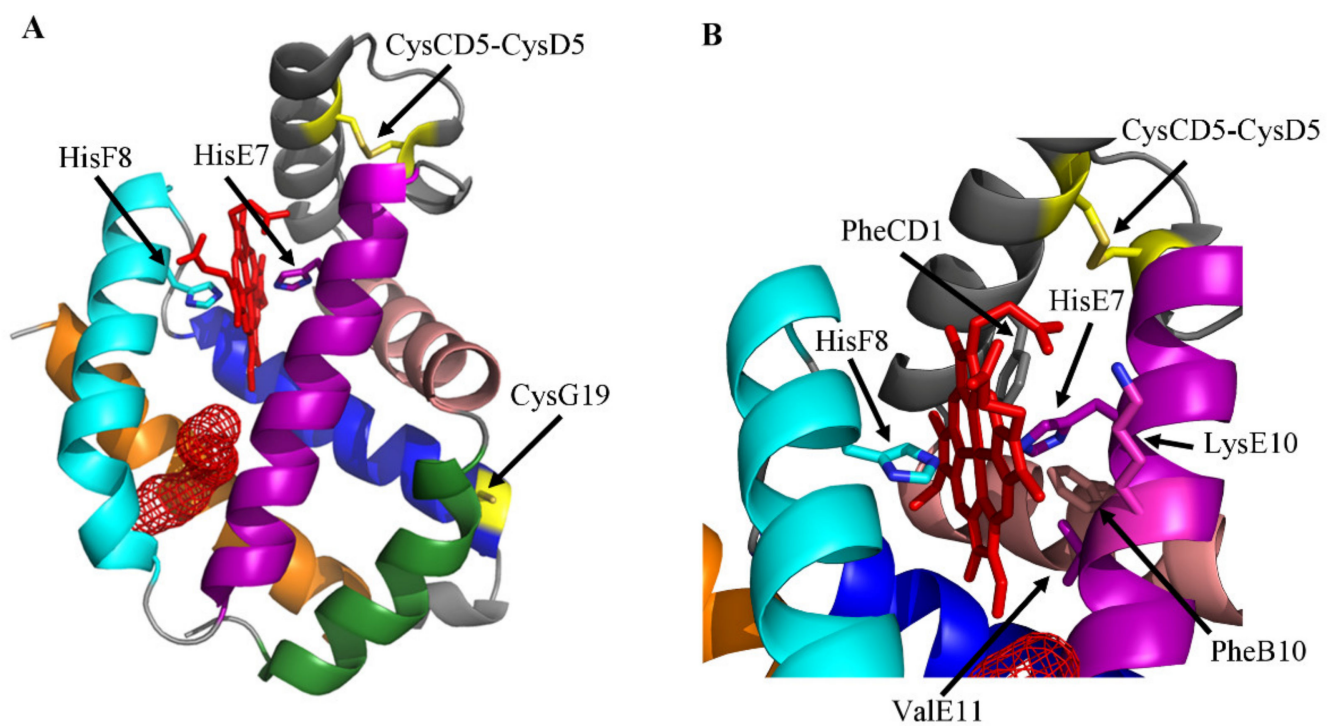

Figure 1. (A) Three-dimensional structure of wild-type human Ngb (ID PDB code: 4MPM) [53]. A, B, $\mathrm{E}, \mathrm{F}, \mathrm{G}$, and $\mathrm{H} \alpha$-helices, forming the classical 3/3 sandwich, are in forest green, salmon, purple, cyan, blue, and orange, respectively. Mesh surfaces of cavity/tunnel systems are highlighted in red. The CysCD5-CysD5 bridge and the CysG19 residue are highlighted in yellow. The proximal and distal amino acid residues HisF8 and HisE7, respectively, axially coordinating the heme-Fe atom through the $\mathrm{N} \varepsilon$ atom, are shown as balls and sticks. Tunnel/cavity systems have been determined by the interactive software CAVER Web 1.1 [68]. (B) Close-up of the heme pocket showing relevant residues cited in the text, in ball and stick representation. Figures drawn by PyMOL package [69].

\section{Ngb (Pseudo-)Enzymatic Properties}

$\mathrm{Ngb}$ is present at a relatively low concentration $(\sim 1 \mu \mathrm{M})$ compared to that of $\mathrm{Mb}$ $(\sim 200-400 \mu \mathrm{M})$ in most tissues and organs; this suggests that the role of $\mathrm{Ngb}$ in $\mathrm{O}_{2}$ supply and/or facilitated diffusion may become significant only in the retinal ganglion cell (RGC) layer and in the optic nerve where the Ngb concentration is up to $100-200 \mu \mathrm{M}[18,70-73]$. Despite its low concentration, Ngb displays (pseudo-)enzymatic properties including $\mathrm{NO} / \mathrm{O}_{2}$, peroxynitrite, and free radical scavenging; nitrite, hydroxylamine, and hydrogen sulfide reduction; and the nitration of aromatic compounds [44].

Of note, the heme-based reactivity of human Ngb is allosterically modulated by the redox state of the cell. In fact, the six-to-five-coordination transition (i.e., the inactiveto-active state) of the heme-Fe atom depends on the cleavage or the formation of the CysCD5-CysD5 bond, belonging to the so-called "dynamic loop" (CD loop/ $\alpha$-helix D region), and the (de-)phosphorylation of SerA7, SerA12, SerAB2, SerCD10, SerCD11, and SerDE3 [32,53,74-77].

\section{The Cleavage of the HisE7-Heme-Fe Bond Modulates the Ngb Reactivity}

The reactivity of six-coordinated human and murine Ngb is modulated through the minimum three-state mechanism encompassing (i) the dissociation of the endogenous ligand HisE7 from the HisF8-Fe-HisE7 complex, (ii) the formation of the transient fivecoordinated HisF8-Fe adduct, and (iii) the association of the exogenous ligand (i.e., L) leading to the formation of the HisF8-Fe-L complex [35,74,78-80] (Figures 1 and 2). The rate of HisE7 dissociation (i.e., $k_{-1}$ ) limits the heme reactivity only under conditions where 
the formation of the transient five-coordinated HisF8-Fe adduct is slower than the rate of exogenous ligand binding to the metal center [8,44,81-83]. Of note, the five-coordinated HisF8-Fe adduct of Symsagittifera roscoffensis Ngb1 may represent the transient reactive adduct of six-coordinated human and murine Ngb (Figures 1 and 2) [50].
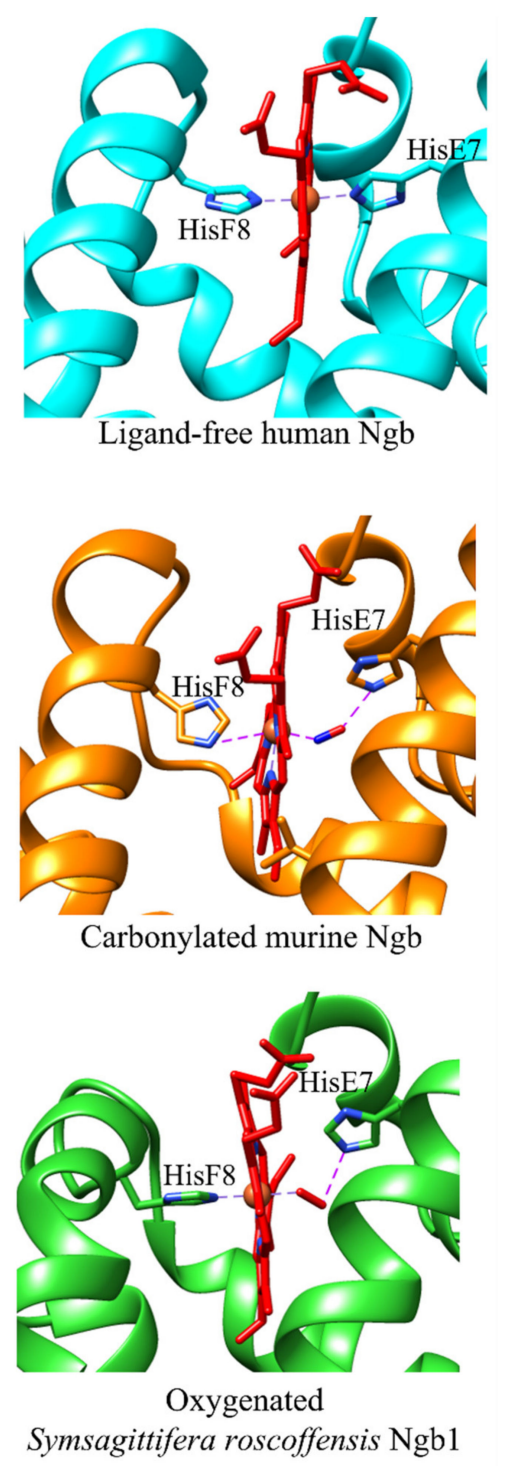

Figure 2. Heme cavities of six-coordinated ligand-free human Ngb (ID PDB code: 1OJ6) [32], carbonylated murine Ngb (ID PDB code: 1Q1F) [35], and oxygenated Symsagittifera roscoffensis Ngb1 (ID PDB code: 4B4Y) [50]. All pictures have been drawn by UCSF-Chimera package [84].

Values of $k_{+1}$ for HisE7 binding to human $\mathrm{Ngb}(\mathrm{II})$ range from $2.0 \times 10^{3} \mathrm{~s}^{-1}$ to $9.8 \times 10^{3} \mathrm{~s}^{-1}\left(\mathrm{pH} 7.0\right.$ and $\left.20.0-25.0^{\circ} \mathrm{C}\right)$, and the value of $k_{+1}$ for HisE7 binding to murine $\mathrm{Ngb}$ (II) is $2.0 \times 10^{3} \mathrm{~s}^{-1}\left(\mathrm{pH} 7.0\right.$ and $20.0{ }^{\circ} \mathrm{C}$ ) [85]. Values of $k_{-1}$ for HisE7 dissociation from human $\mathrm{Ngb}(\mathrm{II})$ range between $1.0 \times 10^{-1} \mathrm{~s}^{-1}$ and $8.2 \times 10^{3} \mathrm{~s}^{-1}(\mathrm{pH} 7.0$ and $20.0-25.0^{\circ} \mathrm{C}$ ), and $k_{-1}$ values of murine $\mathrm{Ngb}$ (II) range between $1.5 \times 10^{-1} \mathrm{~s}^{-1}$ and $1.2 \mathrm{~s}^{-1}$ (pH 7.0 and $20.0-25.0^{\circ} \mathrm{C}$ ) [16,44,78-80,85-91]. In the case of $\mathrm{Ngb}(\mathrm{III})$ the value of $k_{-1}$ for the dissociation of HisE7 is $>4.5 \times 10^{-1} \mathrm{~s}^{-1}$ (pH 7.2 and room temperature) [92]. The different values of $k_{+1}$ and $k_{-1}$ of human and murine $\mathrm{Ngb}[32,34,35]$ reflect, among others, the heme isomerization, the coordination state of the heme-Fe atom, and/or the chemical modifications affecting the heme-Fe reactivity $[74,77,93,94]$. In particular, the $k_{-1}$ value of human $\mathrm{Ngb}$ (II) changes from $6.0 \times 10^{-1} \mathrm{~s}^{-1}$ to $7.0 \mathrm{~s}^{-1}$, reflecting the cleavage and the occurrence of the CysCD5-CysD5 bridge, respectively [74]. In contrast, the $k_{-1}$ 
value of murine $\mathrm{Ngb}(\mathrm{II})\left(1.0 \times 10^{-1} \mathrm{~s}^{-1} ; \mathrm{pH} 7.0\right.$ and $\left.25.0^{\circ} \mathrm{C}\right)$ [76] is unaffected by the redox state of the cell since the CD5 residue is Gly [44]. However, since in many of the following reactions the reduced $\mathrm{Ngb}$ (II) species is the most active form, a very important role for the $\mathrm{Ngb}$ metabolic function is played by the disulfide redox balance as well as by the kinetics of distal histidine coordination with the heme's iron (Figure 3) [95].

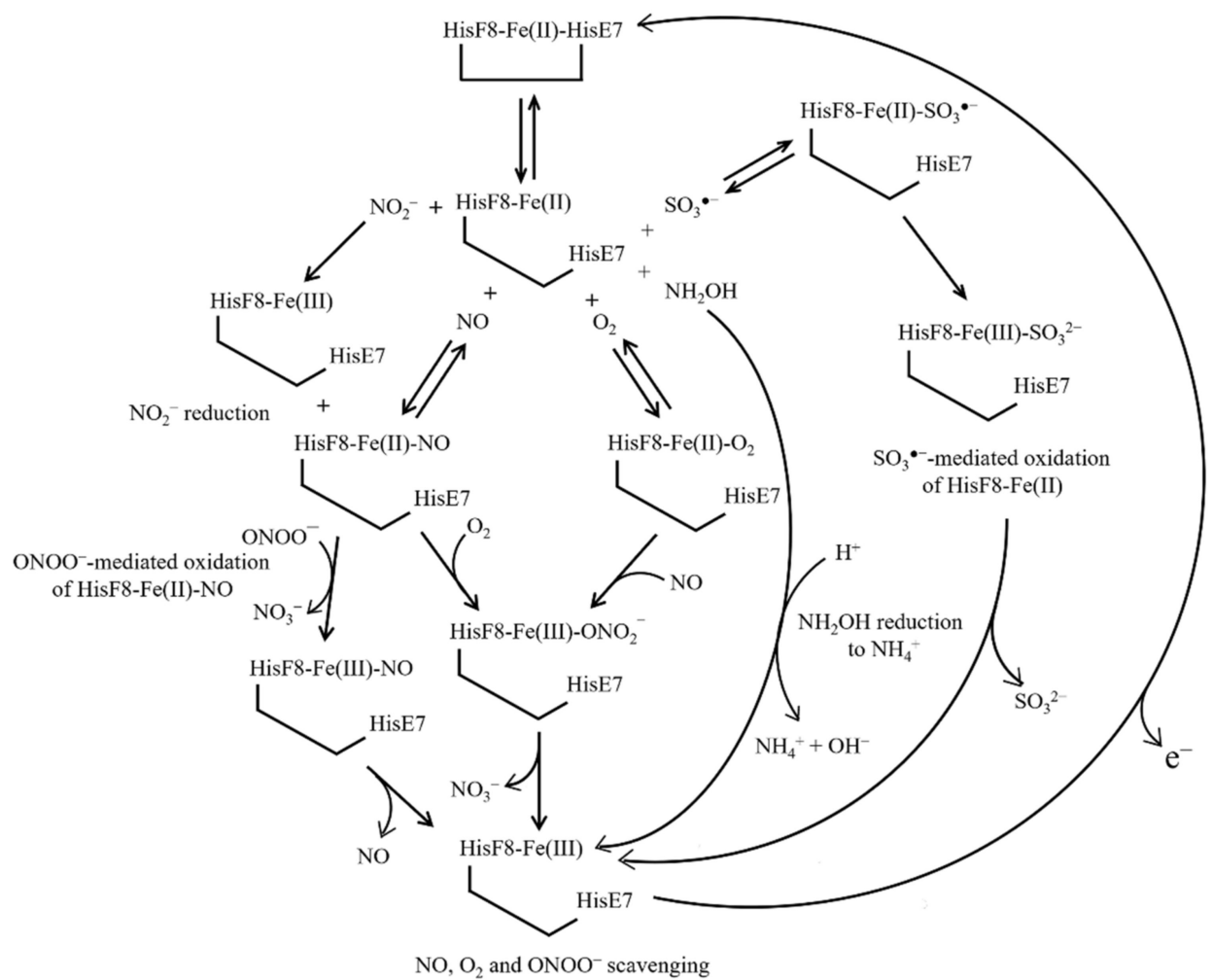

Figure 3. (Pseudo-)enzymatic properties of Ngb(II). The Ngb unreactive hexacoordinated HisF8 $\mathrm{Fe}(\mathrm{II})$-HisE7 species and the reactive pentacoordinated HisF8-Fe(II) conformation are highlighted.

Interestingly, the heme-Fe reactivity of six-coordinated Ngb is similar to that of fivecoordinated globins (e.g., $\mathrm{Mb}$ ), although it is modulated by the strength of the HisE7-Fe bond (about $-3 \mathrm{kcal} \mathrm{mol}^{-1}$ ) rather than by the ligand accessibility to the heme pocket through the E7 gate, possibly reflecting a case of convergent evolution $[8,32,34,35,37,38,44$, 50,53,55-59,67,76,96-103].

\section{Ngb(II) Oxygenation}

The brain is the most energetically demanding organ, but it displays a limited capacity to store energy; therefore, it is highly dependent on $\mathrm{O}_{2}$ and glucose supply from the blood stream [8,44,104-107]. Human and murine $\mathrm{Ngb}$ (II) binds reversibly to $\mathrm{O}_{2}$ with values of the Hill coefficient $n$ close to unity, as expected for monomeric globins $[8,44]$. Values of $P_{50}$ for human $\mathrm{Ngb}(\mathrm{II})$ oxygenation range between $0.9 \mathrm{mmHg}$ and $10 \mathrm{mmHg}$ ( $\mathrm{pH} 7.0$ and $25.0^{\circ} \mathrm{C}$ ), thus reflecting the different globin activation states, whereas the $P_{50}$ value for murine $\mathrm{Ngb}(\mathrm{II})$ oxygenation is $2.2 \mathrm{mmHg}\left(\mathrm{pH} 7.0\right.$ and $\left.25.0^{\circ} \mathrm{C}\right)$. Since human and murine $\mathrm{Ngb}$ (II) oxygenation is limited by the cleavage of the heme-Fe-HisE7 bond, values of the intrinsic dissociation equilibrium constant for $\mathrm{O}_{2}$ binding to the transient five-coordinated species are lower than those of the six-coordinated state by about three orders of magnitude [8,14,44,74,78,80,85,86,108-112].

The rate of $\mathrm{O}_{2}$ binding to six-coordinated $\mathrm{Ngb}$ (II) (i.e., $k_{+2}$ ), as measured by rapidmixing, is independent of the ligand (e.g., $\mathrm{O}_{2}, \mathrm{CO}$, and $\mathrm{NO}$ ) and of the $\mathrm{O}_{2}$ concentration, being limited by the cleavage of the heme-Fe-HisE7 bond (i.e., $k_{-1}$ ). Values of $k_{+2}$ for human $\mathrm{Ngb}(\mathrm{II})$ oxygenation range from $6.0 \times 10^{-1} \mathrm{~s}^{-1}$ to $7.0 \mathrm{~s}^{-1}\left(\mathrm{pH} 7.0\right.$ and $25.0^{\circ} \mathrm{C}$ ), reflecting 
the redox state of the CysCD5/CysD5 residue pair [74]. Since this disulfide bridge is absent in murine $\mathrm{Ngb}(\mathrm{II})$, the value of $k_{+2}$ for the heme-protein oxygenation $\left(1.5 \times 10^{-1} \mathrm{~s}^{-1}\right.$; $\mathrm{pH} 7.0$ and $25.0^{\circ} \mathrm{C}$ ) is independent of the cell redox properties $[74,79,80]$. The value of the second-order rate constant for the oxygenation of five-coordinated human and murine $\mathrm{Ngb}(\mathrm{II})\left(k_{+3}\right)$, as measured after flash and laser photolysis, is $\sim 2.0 \times 10^{8} \mathrm{M}^{-1} \mathrm{~s}^{-1}(\mathrm{pH} 7.0$ and $25.0{ }^{\circ} \mathrm{C}$ ) and the first-order rate constant for $\mathrm{Ngb}(\mathrm{II})-\mathrm{O}_{2}$ deoxygenation (i.e., $k_{-3}$ ) is $\sim 6.0 \times 10^{-1} \mathrm{~s}^{-1}\left(\mathrm{pH} 7.0\right.$ and $\left.25.0^{\circ} \mathrm{C}\right)[74,78,86,113,114]$ (Figure 3).

\section{6. $\mathrm{Ngb}(\mathrm{II})$ Nitrosylation}

The ubiquitous messenger NO plays pivotal roles in several regulatory functions, including vasodilatation, neurotransmission, and host-defense mechanisms; however, it also displays cytotoxic properties and is involved in a variety of neurodegenerative diseases [115,116]. The reaction of $\mathrm{NO}$ with murine $\mathrm{Ngb}(\mathrm{II})$, measured by rapid-mixing (i.e., $\left.k_{+4}\right)$, is slow $\left(\sim 4.0 \times 10^{-1} \mathrm{~s}^{-1}\right.$; $\mathrm{pH} 7.0$ and $\left.20.0^{\circ} \mathrm{C}\right)$ and independent of the ligand concentration because it can only occur upon cleavage of the heme-Fe(II)-HisE7 bond limiting the association of the external ligand [79]. Flash photolysis study shows a fast recombination rate (i.e., $k_{+5}=1.5 \times 10^{8} \mathrm{M}^{-1} \mathrm{~s}^{-1}$; $\mathrm{pH} 7.0$ and $25.0^{\circ} \mathrm{C}$ ) and a low dissociation rate $\left(k_{-5}=2.0 \times 10^{-4} \mathrm{~s}^{-1} ; \mathrm{pH} 7.0\right.$ and $\left.25.0^{\circ} \mathrm{C}\right)$ for murine $\mathrm{Ngb}$ (II) (de)nitrosylation, indicating a high intrinsic affinity for the ligand $\left(K_{5}=1.3 \times 10^{-12} \mathrm{M}\right.$; pH 7.0 and $\left.25.0^{\circ} \mathrm{C}\right)$. However, since $\mathrm{NO}$ binding to murine $\mathrm{Ngb}(\mathrm{II})$ is affected by competitive inhibition of the HisE7 residue $\left(K_{1} \sim 1.0 \times 10^{-3} ; \mathrm{pH} 7.0\right.$ and $\left.25.0^{\circ} \mathrm{C}\right)[74,78]$, the observed $\mathrm{NO}$ affinity decreases by about three orders of magnitude. As expected, NO affinity for ferrous fivecoordinated HisE7Val, HisE7Gln, and HisE7Leu mutants corresponds to the intrinsic affinity of the wild-type heme-protein [113] (Figure 3).

\section{7. $\mathrm{NO}$ and $\mathrm{O}_{2}$ Scavenging from $\mathrm{Ngb}(\mathrm{II})-\mathrm{O}_{2}$ and $\mathrm{Ngb}$ (II)-NO}

$\mathrm{Ngb}$ could be involved in the protection of the brain form damage, either scavenging $\mathrm{O}_{2}$ or detoxifying $\mathrm{NO}[79,92]$. Human and murine $\mathrm{Ngb}(\mathrm{II})-\mathrm{O}_{2}$ and $\mathrm{Ngb}(\mathrm{II})-\mathrm{NO}$ react with $\mathrm{NO}$ and $\mathrm{O}_{2}$, respectively, yielding $\mathrm{Ngb}(\mathrm{III})$ and $\mathrm{NO}_{3}{ }^{-}$as the final products and preventing, among others, protein nitration [79,92,117,118]. The reaction of human and murine $\mathrm{Ngb}$ (II)- $\mathrm{O}_{2}$ with $\mathrm{NO}$ proceeds via the transient intermediate $\mathrm{Ngb}$ (III)$\mathrm{ONO}_{2}{ }^{-}$, which dissociates mono-exponentially with values of the first-order rate constant (i.e., $k_{-6}$ ) of $\sim 3.6 \times 10^{2} \mathrm{~s}^{-1}$ and $\sim 3.0 \times 10^{2} \mathrm{~s}^{-1}$, respectively $\left(\mathrm{pH} 7.0\right.$ and $20.0^{\circ} \mathrm{C}$ ) $[79,118]$. $\mathrm{O}_{2}$ detoxification from human $\mathrm{Ngb}$ (II)-NO is a biphasic process, with values of the secondorder rate constant $\left(k_{+7}\right)$ being $1.6 \times 10^{1} \mathrm{M}^{-1} \mathrm{~s}^{-1}$ and $4.0 \times 10^{-1} \mathrm{M}^{-1} \mathrm{~s}^{-1}(\mathrm{pH} 7.0$ and $25.0^{\circ} \mathrm{C}$ ) [92]. Since values of the bimolecular rate constant for $\mathrm{O}_{2}$ and $\mathrm{NO}$ binding to five-coordinated human $\mathrm{Ngb}$ (II) are almost identical $\left(k_{+3} \sim k_{+5} \sim 10^{8} \mathrm{M}^{-1} \mathrm{~s}^{-1}\right)$, the in vivo formation of $\mathrm{Ngb}(\mathrm{II})-\mathrm{NO}$ is unlikely, occurring only under conditions where NO levels exceed those of $\mathrm{O}_{2}$ [79] (Figure 3).

\section{8. $\mathrm{NO}_{2}{ }^{-}$Reduction by $\mathrm{Ngb}$ (II)}

Human $\mathrm{Ngb}(\mathrm{II})$ catalyzes the reduction of $\mathrm{NO}_{2}{ }^{-}$, leading to the formation of $\mathrm{Ngb}(\mathrm{III})$, $\mathrm{Ngb}(\mathrm{II})-\mathrm{NO}$, and NO. This process is modulated by the redox-sensitive CysCD5 and CysD5 residues regulating the fraction of the highly reactive five-coordinated state of the heme$\mathrm{Fe}(\mathrm{II})$ atom. Therefore, the value of the second-order rate constant $\left(k_{+8}\right)$ for $\mathrm{NO}_{2}{ }^{-}$reduction by human $\mathrm{Ngb}$ (II) increases from $6.2 \times 10^{-2} \mathrm{M}^{-1} \mathrm{~s}^{-1}$ to $1.2 \times 10^{-1} \mathrm{M}^{-1} \mathrm{~s}^{-1}$ ( $\mathrm{pH} 7.4$ and $25.0^{\circ} \mathrm{C}$ ) upon formation of the CysCD5-CysD5 disulfide bond. This small effect was observed in vitro and may not be significant in vivo.

Investigations based on the PheB10Val, PheB10His, PheB10Trp, PheB10Leu, HisE7Ala, HisE7GIn, HisE7Trp, ValE11Ala, ValE11Phe, and ValE11Ile mutants indicate that the reductase activity of human $\mathrm{Ngb}$ (II) depends on the heme accessibility of $\mathrm{NO}_{2}^{-}[119,120]$. Moreover, phosphorylation at putative sites SerA7, SerA12, SerAB2, SerCD10, SerCD11, and SerDE3 by intracellular kinases (e.g., ERK and PKA) increases the nitrite reductase activity of human $\mathrm{Ngb}$ (II) by stabilizing the five-coordinated heme-Fe(II) atom. Of note, the 
binding of the scaffold protein 14-3-3 at putative sites ArgA9-ProAB3 and ArgCD7-ProD1 of human Ngb stabilizes the phosphorylated derivative, enhancing the nitrite reductase activity [77]

The value of $k_{+8}$ for $\mathrm{NO}_{2}{ }^{-}$reduction by murine $\mathrm{Ngb}$ (II) is $5.1 \mathrm{M}^{-1} \mathrm{~s}^{-1}$ ( $\mathrm{pH} 7.4$ and $\left.25.0^{\circ} \mathrm{C}\right) . \mathrm{Ngb}(\mathrm{III})$ is the main product of the reaction, $\mathrm{Ngb}(\mathrm{II})-\mathrm{NO}$ being lower than $20 \%$. Upon reaction with nitrite, murine $\mathrm{Ngb}$ undergoes $S$-nitrosylation, the CysD5 residue representing the primary site. However, the overall intracellular physiological concentration of $\mathrm{NO}_{2}{ }^{-}\left(<1 \times 10^{-5} \mathrm{M}\right)$ appears too low to convert $\mathrm{Ngb}$ to its $S$-nitrosylated derivative acting as a NO depot, but it may play a role in redox signaling pathways [121] (Figure 3).

\section{9. $\mathrm{NH}_{2} \mathrm{OH}$ Reduction by $\mathrm{Ngb}(\mathrm{II})$}

$\mathrm{Hbs}$ reduce nitrite and hydroxylamine, an intermediate of nitrite reductase, to nitric oxide under anaerobic conditions. However, plant and cyanobacterial Hbs catalyze the reduction of hydroxylamine to ammonium at rates 100-2500 times faster than animal globins, including Ngb. These results support the view that plant and cyanobacterial hemoglobins contribute to anaerobic nitrogen metabolism in support of anaerobic respiration and survival during hypoxia [122-124]. Under anaerobic conditions, human $\mathrm{Ngb}(\mathrm{II})$ reduces $\mathrm{NH}_{2} \mathrm{OH}$ to $\mathrm{NH}_{4}{ }^{+}$, being converted to $\mathrm{Ngb}(\mathrm{III})$. The second-order rate constant for hydroxylamine reduction to ammonium by human $\mathrm{Ngb}(\mathrm{III})\left(k_{+8}\right)$ is $<2.5 \times 10^{1} \mathrm{M}^{-1} \mathrm{~s}^{-1}$ [122] (Figure 3).

\section{0. $\mathrm{Ngb}(\mathrm{II})$ Oxidation by $\mathrm{ONOO}^{-}$and $\mathrm{SO}_{3}^{\bullet-}$}

Peroxynitrite induces the oxidation of human $\mathrm{Ngb}(\mathrm{II})-\mathrm{NO}$ by means of the $\mathrm{Ngb}$ (III)-NO transient species that decays to $\mathrm{Ngb}$ (III) and NO. The oxidation of Ngb(II)-NO to $\mathrm{Ngb}$ (III)-NO depends linearly on the $\mathrm{ONOO}^{-}$concentration, whereas the dissociation of the $\mathrm{Ngb}$ (III)-NO complex is a monomolecular process (Figure 3). The value of the second-order rate constant for the $\mathrm{ONOO}^{-}$-dependent oxidation of $\mathrm{Ngb}(\mathrm{III})-\mathrm{NO}\left(k_{+7}\right)$ is $1.3 \times 10^{5} \mathrm{M}^{-1} \mathrm{~s}^{-1}$ and the value of the first-order rate constant of the $\mathrm{Ngb}$ (III)-NO dissociation $\left(k_{-7}\right)$ is $1.2 \times 10^{-1} \mathrm{~s}^{-1}\left(\mathrm{pH} 7.2\right.$ and $20.0^{\circ} \mathrm{C}$ ) [92]. Murine $\mathrm{Ngb}$ (II) undergoes oxidation by $\mathrm{SO}_{3}{ }^{\bullet-}$ sulfur trioxide, yielding $\mathrm{Ngb}(\mathrm{III})$ and $\mathrm{SO}_{3}{ }^{-}$as final products; the bimolecular rate constant (i.e., $k_{+8}$ ) is $2.6 \times 10^{9} \mathrm{M}^{-1} \mathrm{~s}^{-1}\left(\mathrm{pH} 7.2\right.$ and $37.0^{\circ} \mathrm{C}$ ). Since $\mathrm{SO}_{3}^{\bullet-}$ scavenging by $\mathrm{Ngb}$ (II) is inhibited by glutathione, this reaction may take place in the retina where $\mathrm{Ngb}(\mathrm{II})$ levels are exceeding those of glutathione [125] (Figure 3).

\section{Reductive Nitrosylation of Ngb(III)}

The reaction of human $\mathrm{Ngb}(\mathrm{III})$ with an excess of $\mathrm{NO}$ leads to $\mathrm{Ngb}(\mathrm{II})-\mathrm{NO}$ via the formation of the transient $\mathrm{Ngb}$ (III)-NO adduct. Values of the dissociation equilibrium constant $\left(K_{9}\right)$ and of the second-order rate constant $\left(k_{+9}\right)$ for $\mathrm{NO}$ binding to human $\mathrm{Ngb}(\mathrm{III})$ are $7.5 \times 10^{-5} \mathrm{M}$ and $2.0 \times 10^{3} \mathrm{M}^{-1} \mathrm{~s}^{-1}$, respectively $\left(\mathrm{pH} 7.0\right.$ and $20.0{ }^{\circ} \mathrm{C}$ ) [118]. The value of the first-order rate constant for the dissociation of $\mathrm{NO}$ from Fe(III)-NO (i.e., $k_{-9}$ ) is $1.2 \times 10^{-1} \mathrm{~s}^{-1}$ [92]. The reductive nitrosylation of human $\mathrm{Ngb}$ (III) is a biphasic process; values of the overall second-order rate constant of the fast and the slow components (i.e., $k_{+10}$ ) are $2.1 \times 10^{1} \mathrm{M}^{-1} \mathrm{~s}^{-1}$ and $2.9 \mathrm{M}^{-1} \mathrm{~s}^{-1}\left(\mathrm{pH} 7.0\right.$ and $25.0{ }^{\circ} \mathrm{C}$ ), respectively. The transient Fe(III)-NO species converts to Fe(II)-NO with a mono-exponential process, the value of the first-order rate constant (i.e., $\left.k_{+11}\right)$ being $>2.4 \times 10^{-2} \mathrm{~s}^{-1}(\mathrm{pH} 7.0$ and $25.0{ }^{\circ} \mathrm{C}$ ) [92] (Figure 4). 


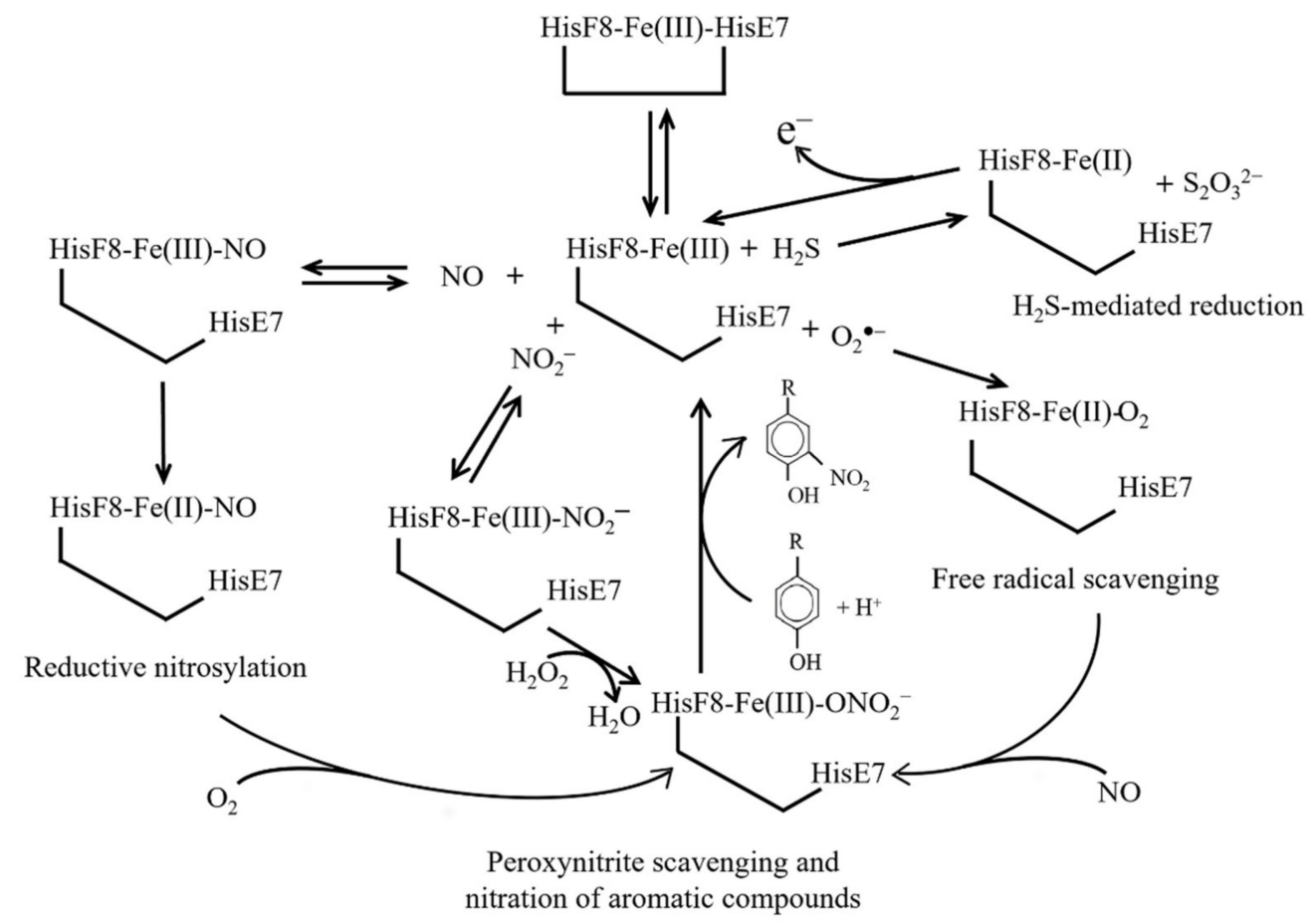

Figure 4. (Pseudo-)enzymatic properties of Ngb(III). The Ngb unreactive hexacoordinated HisF8$\mathrm{Fe}(\mathrm{III})$-HisE7 species and the reactive pentacoordinated HisF8-Fe(III) conformation are highlighted.

\section{2. $\mathrm{H}_{2} \mathrm{~S}$-Mediated Reduction of Ngb(III)}

Hydrogen sulfide $\mathrm{H}_{2} \mathrm{~S}$ is a potential signaling molecule produced by cystathionine $\beta$-synthase, cystathionine $\gamma$-lyase, and 3-mercaptopyruvate sulfurtransferase. $\mathrm{H}_{2} \mathrm{~S}$ affects neurotransmission in the brain and relaxes vascular smooth muscle in synergy with NO. Moreover, it has been reported that $\mathrm{H}_{2} \mathrm{~S}$ acts as an $\mathrm{O}_{2}$ sensor, influences autophagy, displays a cytoprotective and angioprotective effect during the evolution of myocardial infarction, and has anti- inflammatory activity [126]. In addition, the hydrogen polysulfides $\left(\mathrm{H}_{2} \mathrm{Sn}\right.$, $n \geq 2$ ), produced by 3-mercaptopyruvate sulfurtransferase, are potential signaling molecules able to modulate the activity of ion channels and enzymes as well as the tumor growth by $S$-sulfuration of target proteins [127] (Figure 4).

Under anaerobic conditions, human $\mathrm{Ngb}$ (III) catalyzes the oxidation of $\mathrm{HS}^{-}$to $\mathrm{S}_{2} \mathrm{O}_{3}{ }^{2-}$ via the formation of the transient $\mathrm{Ngb}$ (II)-HS adduct; this reaction exhibits biphasic kinetics. For the fast phase, values of the second-order rate constant for the formation of the $\mathrm{Ngb}(\mathrm{II})-\mathrm{HS}$ complex $\left(k_{+12}\right)$, of the first-order rate constant for the $\mathrm{Ngb}(\mathrm{II})-\mathrm{HS}$ adduct dissociation $\left(k_{-12}\right)$, and of the equilibrium dissociation constant for $\mathrm{H}_{2} \mathrm{~S}$ binding to $\mathrm{Ngb}$ (III) $\left(K_{12}\right)$ are $1.4 \times 10^{1} \mathrm{M}^{-1} \mathrm{~s}^{-1}, 5.1 \times 10^{-3} \mathrm{~s}^{-1}$, and $3.7 \times 10^{-4} \mathrm{M}\left(\mathrm{pH} 7.4\right.$ and $\left.25.0^{\circ} \mathrm{C}\right)$, respectively. On the other hand, the rate constant of the slow step for $\mathrm{Ngb}$ (II)-HS complexation $\left(k_{+13}=5.6 \times 10^{-4} \mathrm{~s}^{-1} ; \mathrm{pH} 7.4\right.$ and $\left.25.0^{\circ} \mathrm{C}\right)$ is independent of the ligand concentration. The $\mathrm{Ngb}(\mathrm{III})$ mutant HisE7Ala was more active for $\mathrm{H}_{2} \mathrm{~S}$ oxidation $\left(k_{+14}=1.4 \times 10^{1} \mathrm{M}^{-1} \mathrm{~s}^{-1}\right.$, $k_{-14}=5.1 \times 10^{-3} \mathrm{~s}^{-1}$, and $K_{14}=3.7 \times 10^{-4} \mathrm{M} ; \mathrm{pH} 7.4$ and $25.0^{\circ} \mathrm{C}$ ), yielding the formation of 2-6 catenated sulfur atoms with or without oxygen insertion. This highlights the role of the heme distal residue in modulating the reactivity of the metal center and the different reaction options [127-131] (Figure 4).

\section{Free Radical Scavenging from $\mathrm{Ngb}(\mathrm{III})$}

Human $\mathrm{Ngb}$ (III) scavenges a variety of free radicals including $\mathrm{O}_{2}{ }^{\bullet-}$. The value of the affinity constant $\left(K_{15}\right)$ for $\mathrm{O}_{2}{ }^{\bullet-}$ binding to $\mathrm{Ngb}$ (III) is $7.4 \times 10^{-6} \mathrm{M}$. The CysCD5-CysD5 bond is not necessary to scavenge superoxide, but it plays a pivotal role in stabilizing the heme-Fe(II)- $\mathrm{O}_{2}$ complex [132]. Wild-type human $\mathrm{Ngb}(\mathrm{III})$ and the PheB10Leu mutant are much more stable in the presence of $\mathrm{H}_{2} \mathrm{O}_{2}$ than the HisE7Leu mutant, which undergoes 
tyrosyl radical formation. This indicates that $(i)$ the PheB10 residue is essentially insensitive to the redox state of $\mathrm{Ngb}$ and (ii) the five-coordination of the heme-Fe atom, occurring in the HisE7Leu mutant, induces the destabilization of the globin fold [133]. As a whole, the redox changes of the heme-Fe atom and of the CysCD5/CysD5 residue pair could regulate neuroprotective functions of human $\mathrm{Ngb}$, protecting against hypoxic and ischemic stress in the brain [132,134] (Figure 4). Of note, human Ngb(III) does not produce the oxidizing oxoFe $(\mathrm{IV})=\mathrm{O}$ species when treated with $\mathrm{H}_{2} \mathrm{O}_{2}$, in contrast to $\mathrm{Hb}$ and $\mathrm{Mb}$ [92].

\section{Nitration of Aromatic Compounds by $\mathrm{Ngb}(\mathrm{III})-\mathrm{NO}_{2}$}

Nitrosylated tyrosines play a role in the redox regulation of metabolism; however, their increase occurs in multiple neurodegenerative diseases (e.g., Parkinson's and Alzheimer's diseases) [135]. Human $\mathrm{Ngb}(\mathrm{III})-\mathrm{NO}_{2}{ }^{-}$catalyzes the nitration of phenolic substrates in the presence of $\mathrm{H}_{2} \mathrm{O}_{2}$ via the transient formation of the highly reactive $\mathrm{Ngb}(\mathrm{III})-\mathrm{ONOO}^{-}$ species (Figure 4). The two human Ngb forms, with and without the internal CysCD5CysD5 disulfide bridge, reflecting the five- and six-coordination of the heme-Fe(III) atom, respectively, exhibit very different reactivities. In fact, values of the dissociation equilibrium constant (i.e., $K_{16}$ ) and of the second-order rate constant (i.e., $k_{+16}$ ) for the nitration of aromatic compounds by the highly reactive $\mathrm{Ngb}(\mathrm{III})-\mathrm{ONO}_{2}{ }^{-}$complex are $4.3 \times 10^{-2} \mathrm{M}$ and $3.3 \mathrm{M}^{-1} \mathrm{~s}^{-1}$, respectively, whereas those of the slowly reactive form are $2.2 \times 10^{-1} \mathrm{M}$ and $6.3 \times 10^{-1} \mathrm{M}^{-1} \mathrm{~s}^{-1}$, respectively [136]. This evidence reinforces the relevance of the cysteine redox equilibrium in $\mathrm{Ngb}$, which plays an important role in addressing its reactivity toward alternative metabolic pathways (Figures 3 and 4).

\section{Possible Patho-Physiological Roles of Neuroglobin}

Up to now, Ngb-based reactions have been investigated separately without attempting to link them to each other. Here, this limitation has been tentatively overcome to support the view that Ngb plays multiple roles in health and disease [44,137-140].

$\mathrm{Ngb}$ was first documented to be almost exclusively expressed in the brain, displaying high concentrations (up to 100-200 $\mu \mathrm{M}$ ) in the retina layers, not only in the RGC layer, but also in astrocytes and in Müller cells (i.e., a specialized microglial lineage which spans across the layers, serving protective and nourishing activities). In this last cell type, the $\mathrm{Ngb}$ expression is further significantly raised during reactive gliosis in response to eye injury [141].

$\mathrm{Ngb}$ actions in vivo depend on its concentration and on an efficient $\mathrm{Ngb}$ (III) reductase system, still unknown, restoring $\mathrm{Ngb}$ (II) $[44,79,80,118,142]$. Thus, when present at high concentrations $(\sim 100-200 \mu \mathrm{M}) \mathrm{Ngb}$ may facilitate $\mathrm{O}_{2}$ buffer and transport in the RGC layer and the optic nerve, whereas at low concentrations $(\sim 1 \mu \mathrm{M}) \mathrm{Ngb}$ can display only potential enzymatic activities and cell signaling in most tissues and organs, including resting neurons $[43,44,143]$.

Systems biology investigations and numerical simulations confirm that $\mathrm{Ngb}$ should play an important role in $\mathrm{O}_{2}$ transport rather than in storage; thus, since the retina is most susceptible to hypoxia in the regions of the photoreceptor inner segment and inner plexiform layers, high concentrations of $\mathrm{Ngb}$ have the potential to prevent hypoxia and increase the $\mathrm{O}_{2}$ uptake by 30-40\% [144]. A mutual regulation of $\mathrm{Ngb}$ and hypoxia was envisaged by studies on Ngb expression after the induction of ocular hypertension in Wistar rats. Ngb was quickly transcriptionally upregulated in rat retinal layers in response to the acute retinal ischemia injury induced by the elevation of intraocular pressure, suggesting that the globin might play an important role in the metabolic adaptation to hypoxia [145].

Furthermore, decreased survival of Ngb-deficient primary cortical neurons along with increased viability of the same cells in the presence of $\mathrm{Ngb}$ overexpression were originally reported in an experimental model of hypoxia in vitro, where Ngb immunostaining was significantly increased in the surviving infarcted area [146]. In accordance with these findings, the intra-cerebro-ventricular administration of a Ngb antisense, but not sense, oligo-deoxynucleotide increased infarct volume, worsening the neurological outcome of stroke [147]. 
The hypothesis of Ngb having a role in reducing the focal ischemia and infarct size was further pushed forward by the development of transgenic mice overexpressing this globin (Ngb-Tg mice). A reduced infarct size was observed in these animals after transient cerebral arterial ligation followed by reperfusion [148]. Surprisingly, in this transgenic animal, Ngb expression was induced also in non-neuronal cells, such as in heart cells, and this was apparently enough to limit the infarct size area after heart arterial ligation and reperfusion, also in an organ which physiologically does not appreciably express the protein [148]. The reduced infarct size in the same Ngb-Tg animal was further confirmed by other authors [149].

Furthermore, the specific effect of increasing the amount of $\mathrm{Ngb}$ in retinal cells has been demonstrated by the injection of exogenous Ngb after a transient hypoxia, which turned out to be effective in decreasing the levels of inflammatory chemokines (IL-6, TNF $\alpha$, IL-1B, RANTES, MCP-1, and VEGF) and microglia activation [150]. This effect appears to be linked to the regulatory effect of Ngb on the Wnt/ $\beta$-catenin and NF- $k B$ signaling pathways, which is exerted mostly through the induction of the proteasomal degradation of Dishevelled-1, a key hub protein eliciting these two processes [151].

Interestingly, endogenous, and exogenous compounds (e.g., hormones and phytochemicals) as well as injuries (e.g., oxidative stress, hypoxia, epilepsy, and ischemia) increase Ngb levels in the brain, allowing it to carry out functions directed to neuroprotection [152-156]. As a matter of fact, the enhanced expression of Ngb has been observed in RGCs after optical nerve injury either through exposure to intense led light [157] or to an oxidative stress [158].

Clues for interpreting the biological role of $\mathrm{Ngb}$ come from zebrafish retina, which, unlike mammals, shows regenerative properties of the optic nerve. In this small fish, $\mathrm{Ngb}$ mRNA was found to be expressed in amacrine cells, whereas Ngb protein was also detected in the inner plexiform layer. This discrepancy was attributable to the presence of a membrane-penetrating module of zebrafish $\mathrm{Ngb}$ which allowed the protein to cross the plasma membrane. Immuno-histochemical studies after optic nerve injury highlighted that $\mathrm{Ngb}$ protein levels were increased in both amacrine cells, in correspondence to the nerve ending processes, and presynaptic regions in the inner plexiform layer, suggesting that $\mathrm{Ngb}$ might be released by the former cells and picked up by the ganglion cells, wherein it participates in the regeneration of the axon [159].

Although most of details of the mechanisms through which Ngb exerts its neuroprotective activity are still unclear, co-localization studies in the retina have confirmed a strong interaction of the globin with mitochondria, envisaging a role in assisting energy metabolism and in patrolling apoptosis upon release of mitochondrial factors, such as cytochrome $c$. In this respect, a very important role seems to be played by Ngb in the protection of nerve cells from apoptosis, mainly through its interaction with cytochrome $c[118,160]$, which can block the activation of caspase 9 by ferric cytochrome $c[161,162]$. This anti-apoptotic function requires a reduced $\mathrm{Ngb}$ (II) which interacts with ferric cytochrome $c$ through negatively charged residues (mostly Asp73 and to a reduced extent Glu60, Asp63, and Glu87); this complex quickly reduces cytochrome $c$, impairing its pro-apoptotic role [163].

Some clues strengthening the contribution of $\mathrm{Ngb}$ in serving mitochondria functionality come from studies on the Harlequin mouse phenotype, which finds its genetic roots in the depletion of the apoptosis-inducing factor, and recapitulates hallmarks of human neurodegenerative mitochondrial pathologies, such as the age-dependent degeneration of the retina, optic nerve, cerebellum, and cortical regions. Rescue of Ngb expression in the retina, which significantly drops in the brain of the Harlequin mouse upon delivery of an adenovirus associated vector (AAV), improved RGC survival and overall retina neurodegeneration, suggesting that restoring adequate Ngb levels was enough to improve the mitochondrial chain respiration and energy homeostasis [43].

Similarly, the development of Ngb-transgenic (Ngb-Tg) mice has provided a significant technological advancement to point out the effect of $\mathrm{Ngb}$ overexpression on mitochondrial dynamics during retinal ischemia in vivo. Remarkably, compared with wild-type animals, 
$\mathrm{Ngb}-\mathrm{Tg}$ mice showed a relevant decrease of mitochondrial DNA damage after 7 days of reperfusion following ischemia induction. In accordance with the general neuroprotective activity of Ngb, apoptosis markers, such as the release of the caspase-3 active fragment, were decreased in Ngb-Tg mice and TUNEL assay showed a reduced frequency of apoptotic cells [152].

Further, several studies have suggested that mitochondrial dysfunction may induce retinal degenerative disorders, such as glaucoma, and that Ngb is among the genes transcriptionally downregulated during the glaucoma onset [143]. For this, the role of Ngb has been investigated in a well-established model of retinal neurodegeneration, such as the DBA/2J mice (which develop spontaneous intraocular pressure and RGC degeneration, eventually inducing glaucoma), following the effect of Ngb upregulation in RGCs via a single intravitreal injection of an AAV vector. In these animals, because of decreased enzymatic activities of mitochondrial chain complexes, mitochondrial dysfunction precedes RGC loss by about 5 months, but AAV-Ngb administration led to a general and robust improvement of RGC functionality. Furthermore, immuno-histochemical studies of retina sections indicated the presence of conserved RGC morphology, suggesting neuronal remodeling and synaptic plasticity. Moreover, overexpression of $\mathrm{Ngb}$ attenuated ocular hypertension-induced superoxide production and the associated decrease of ATP levels in mice, suggesting that $\mathrm{Ngb}$ acts as an endogenous neuroprotectant to reduce oxidative stress and improve mitochondrial function, thereby promoting RGC survival. Thus, Ngb may modulate RGC susceptibility to glaucomatous neural damage [42].

\section{Conclusions and Perspectives}

The neuroprotective role of $\mathrm{Ngb}$ is openly debated since differences in transcript and protein Ngb levels have been reported [149,164-168]. Several studies in Ngb-null mice reported that $\mathrm{Ngb}$ expression in the central nervous system and in the retina, rather than diffuse, is restricted to specific brain regions and to two out of the ten layers forming the retina $[149,169]$.

The use of Ngb-null mice turned out to be important to highlight some important $\mathrm{Ngb}$ functions, since they appear to have a reduced activity of respiratory chain complexes I and III, the degeneration of primary rat RGCs, and the impairment of visual functions [50]. In addition, a 56-60\% increase of the infarct volume after focal cerebral ischemia has been observed in Ngb-null mice compared to wild-type animals [146]. In turn, the reduction in infarct size induced by ischemia has been obtained by increasing the Ngb levels before the onset of stroke [170]. These data highlight the role of Ngb as a compensatory protein (e.g., stress-sensor and stress-inducible macromolecule) responding to hypoxic/ischemic/oxidative injuries by activating survival/antiapoptotic pathways [171,172].

In the future, a better understanding of the molecular mechanisms at the root of the biological functions of $\mathrm{Ngb}$ will bear fundamental and translational significance, especially in the development of therapeutics against stroke and neurological disorders. Ngb-based therapeutic approaches to neurological disorders have started, and the results obtained are promising since no side effects of Ngb overexpression in transgenic mice have been observed $[148,173]$. However, since Ngb may act as a compensatory protein even in cancer cells, the possibility that systemic Ngb overexpression could enhance cancer cell survival should be taken into account considered; in this respect, the possibility of Ngb gene therapy is being considered realistically $[172,174]$.

Author Contributions: Conceptualization, P.A. and M.C.; software, G.D.S. and A.P.; investigation, F.O.; data curation, F.O.; writing — original draft preparation, G.D.S. and D.S.; writing-review and editing, P.A. and M.C.; visualization, A.P.; supervision, P.A. and M.C.; funding acquisition, P.A. and M.C. All authors have read and agreed to publish this manuscript. 
Funding: This work has been supported by the Italian Ministry of Education, Universities and Research (PRIN 2017SNRXH3 and Dipartimenti di Eccellenza; Legge 232/2016, Articolo 1, Comma 314-337) and Fondazione Roma.

Institutional Review Board Statement: Not applicable.

Informed Consent Statement: Not applicable.

Data Availability Statement: Not applicable.

Acknowledgments: The authors wish to thank Maria Marino for helpful discussions. The authors apologize for not having quoted several outstanding papers due to space limitations.

Conflicts of Interest: The authors declare no conflict of interest.

$\begin{array}{ll}\text { Abbreviations } \\ \mathrm{AAV} & \text { Adenovirus associated vector } \\ \mathrm{Adgb} & \text { androglobin } \\ \mathrm{Cygb} & \text { cytoglobin } \\ \mathrm{Hb} & \text { hemoglobin } \\ \mathrm{Mb} & \text { myoglobin } \\ \mathrm{Ngb}(\mathrm{II}) & \text { ferrous Ngb } \\ \mathrm{Ngb}(\mathrm{III}) & \text { ferric } \mathrm{Ngb} \\ \mathrm{GbE} & \text { globin } \mathrm{E} \\ \mathrm{GbX} & \text { globin } \mathrm{X} \\ \mathrm{GbY} & \text { globin } \mathrm{Y} \\ \mathrm{Mb} & \text { myoglobin } \\ \mathrm{Ngb} & \text { neuroglobin } \\ \mathrm{mice} \text { Ngb-Tg } & \text { transgenic mice overexpressing } \mathrm{Ngb} \\ \mathrm{RGC} & \text { retinal ganglion cell }\end{array}$

\section{References}

1. Antonini, E.; Brunori, M. Hemoglobin and Myoglobin in Their Reactions with Ligands; North-Holland Publishing, Co.: Amsterdam, The Netherlands, 1971.

2. Perutz, M.F. Regulation of oxygen affinity of hemoglobin: Influence of structure of the globin on the heme iron. Annu. Rev. Biochem. 1979, 48, 327-386. [CrossRef]

3. Bunn, H.F.; Forget, B.G. Hemoglobin: Molecular, Genetic and Clinical Aspects; W.B. Saunders Co.: Philadelphia, PA, USA, 1986.

4. Bolognesi, M.; Bordo, D.; Rizzi, M.; Tarricone, C.; Ascenzi, P. Nonvertebrate hemoglobins: Structural bases for reactivity. Progr. Biophys. Mol. Biol. 1997, 68, 29-68. [CrossRef]

5. Gilles-Gonzalez, M.A.; Gonzalez, G. Heme-based sensors: Defining characteristics, recent developments, and regulatory hypotheses. J. Inorg. Biochem. 2005, 99, 1-22. [CrossRef]

6. Pesce, A.; Bolognesi, M.; Nardini, M. The diversity of 2/2 (truncated) globins. Adv. Microb. Physiol. 2013, 63, 49-78. [CrossRef]

7. Pesce, A.; Bolognesi, M.; Nardini, M. Protoglobin: Structure and ligand-binding properties. Adv. Microb. Physiol. 2013, 63, 79-96. [CrossRef] [PubMed]

8. Ascenzi, P.; Brunori, M. A molecule for all seasons: The heme. J. Porphyr. Phthalocyanines 2016, 29, 1-16. [CrossRef]

9. Vinogradov, S.N.; Hoogewijs, D.; Bailly, X.; Arredondo-Peter, R.; Gough, J.; Dewilde, S.; Moens, L.; Vanfleteren, J.R. A phylogenomic profile of globins. BMC Evol. Biol. 2006, 6, 31-47. [CrossRef] [PubMed]

10. Vinogradov, S.N.; Moens, L. Diversity of globin function: Enzymatic, transport, storage, and sensing. J. Biol. Chem. 2008, 283, 8773-8777. [CrossRef]

11. Wajcman, H.; Kiger, L.; Marden, M.C. Structure and function evolution in the superfamily of globins. Crit. Rev. Biol. 2009, 332, 273-282. [CrossRef] [PubMed]

12. Burmester, T.; Hankeln, T. Function and evolution of vertebrate globins. Acta Physiol. 2014, 211, 501-514. [CrossRef]

13. Keppner, A.; Maric, D.; Correia, M.; Koay, T.W.; Orlando, I.M.C.; Vinogradov, S.N.; Hoogewijs, D. Lessons from the post-genomic era: Globin diversity beyond oxygen binding and transport. Redox Biol. 2020, 37, 101687-101705. [CrossRef] [PubMed]

14. Burmester, T.; Weich, B.; Reinhardt, S.; Hankeln, T. A vertebrate globin expressed in the brain. Nature 2000, 407, 520-523. [CrossRef]

15. Burmester, T.; Ebner, B.; Weich, B.; Hankeln, T. Cytoglobin: A novel globin type ubiquitously expressed in vertebrate tissues. Mol. Biol. Evol. 2002, 19, 416-421. [CrossRef]

16. Trent, J.T., III; Hargrove, M.S. A ubiquitously expressed human hexacoordinate hemoglobin. J. Biol. Chem. 2002, 277, 19538-19545. [CrossRef] 
17. Fuchs, C.; Burmester, T.; Hankeln, T. The amphibian globin gene repertoire as revealed by the Xenopus genome. Genome Res. 2006, 112, 296-306. [CrossRef] [PubMed]

18. Kugelstadt, D.; Haberkamp, M.; Hankeln, T.; Burmester, T. Neuroglobin, cytoglobin, and a novel, eye-specific globin from chicken. Biochem. Biophys. Res. Commun. 2004, 325, 719-725. [CrossRef]

19. Roesner, A.; Fuchs, C.; Hankeln, T.; Burmester, T. A globin gene of ancient evolutionary origin in lower vertebrates: Evidence for two distinct globin families in animals. Mol. Biol. Evol. 2005, 22, 12-20. [CrossRef]

20. Hoogewijs, D.; Ebner, B.; Germani, F.; Hoffmann, F.G.; Fabrizius, A.; Moens, L.; Burmester, T.; Dewilde, S.; Storz, J.F.; Vinogradov, S.N.; et al. Androglobin: A chimeric globin in metazoans that is preferentially expressed in mammalian testes. Mol. Biol. Evol. 2012, 29, 1105-1114. [CrossRef] [PubMed]

21. Pesce, A.; Couture, M.; Dewilde, S.; Guertin, M.; Yamauchi, K.; Ascenzi, P.; Moens, L.; Bolognesi, M. A novel two-over-two alpha-helical sandwich fold is characteristic of the truncated hemoglobin family. EMBO J. 2000, 19, 2424-2434. [CrossRef]

22. Montfort, W.R.; Weichsel, A.; Andersen, J.F. Nitrophorins and related antihemostatic lipocalins from Rhodnius prolixus and other blood-sucking arthropods. Biochim. Biophys. Acta 2000, 1482, 110-118. [CrossRef]

23. Andersen, J.F. Structure and mechanism in salivary proteins from blood-feeding arthropods. Toxicon 2010, 56, 1120-1129. [CrossRef]

24. Champagne, D.E. Antihemostatic molecules from saliva of blood-feeding arthropods. Pathophysiol. Haemos. Thromb. 2005, 34, 221-227. [CrossRef]

25. De Simone, G.; Ascenzi, P.; Polticelli, F. Nitrobindin: An ubiquitous family of all $\beta$-barrel heme-proteins. IUBMB Life 2016, 68, 423-428. [CrossRef] [PubMed]

26. De Simone, G.; Ascenzi, P.; di Masi, A.; Polticelli, F. Nitrophorins and nitrobindins: Structure and function. Biomol. Concepts 2017, 8, 105-118. [CrossRef]

27. De Simone, G.; di Masi, A.; Vita, G.M.; Polticelli, F.; Pesce, A.; Nardini, M.; Bolognesi, M.; Ciaccio, C.; Coletta, M.; Turilli, E.S.; et al. Mycobacterial and human nitrobindins: Structure and function. Antioxid. Redox Signal. 2020, 33, 229-246. [CrossRef]

28. De Simone, G.; di Masi, A.; Ciaccio, C.; Coletta, M.; Ascenzi, P. NO Scavenging through reductive nitrosylation of ferric Mycobacterium tuberculosis and Homo sapiens nitrobindins. Int. J. Mol. Sci. 2021, 21, 9395. [CrossRef]

29. De Simone, G.; di Masi, A.; Pesce, A.; Bolognesi, M.; Ciaccio, C.; Tognaccini, L.; Smulevich, G.; Abbruzzetti, S.; Viappiani, C.; Bruno, S.; et al. Mycobacterial and human ferrous nitrobindins: Spectroscopic and reactivity properties. Int. J. Mol. Sci. 2021, 22, 1674. [CrossRef] [PubMed]

30. Tilton, R.F.; Kuntz, I.D.; Petsko, G.A. Cavities in proteins: Structure of a metmyoglobin xenon complex solved at 1.9 Å. Biochemistry 1984, 23, 2849-2857. [CrossRef]

31. Milani, M.; Pesce, A.; Ouellet, Y.; Ascenzi, P.; Guertin, M.; Bolognesi, M. Mycobacterium tuberculosis hemoglobin N displays a protein tunnel suited for $\mathrm{O}_{2}$ diffusion to the heme. EMBO J. 2001, 20, 3902-3909. [CrossRef]

32. Pesce, A.; Dewilde, S.; Nardini, M.; Moens, L.; Ascenzi, P.; Hankeln, T.; Burmester, T.; Bolognesi, M. Human brain neuroglobin structure reveals a distinct mode of controlling oxygen affinity. Structure 2003, 11, 1087-1095. [CrossRef]

33. De Sanctis, D.; Dewilde, S.; Pesce, A.; Moens, L.; Ascenzi, P.; Hankeln, T.; Burmester, T.; Bolognesi, M. Mapping protein matrix cavities in human cytoglobin through Xe atom binding. Biochem. Biophys. Res. Commun. 2004, 316, 1217-1221. [CrossRef] [PubMed]

34. Vallone, B.; Nienhaus, K.; Brunori, M.; Nienhaus, G.U. The structure of murine neuroglobin: Novel pathways for ligand migration and binding. Proteins 2004, 56, 85-92. [CrossRef]

35. Vallone, B.; Nienhaus, K.; Matthes, A.; Brunori, M.; Nienhaus, G.U. The structure of carbonmonoxy neuroglobin reveals a heme-sliding mechanism for control of ligand affinity. Proc. Natl. Acad. Sci. USA 2004, 101, 17351-17356. [CrossRef]

36. Nardini, M.; Pesce, A.; Thijs, L.; Saito, J.A.; Dewilde, S.; Alam, M.; Ascenzi, P.; Coletta, M.; Ciaccio, C.; Moens, L.; et al. Archaeal protoglobin structure indicates new ligand diffusion paths and modulation of haem-reactivity. EMBO Rep. 2008, 9, 157-163. [CrossRef]

37. Arroyo-Mañez, P.; Bikiel, D.E.; Boechi, L.; Capece, L.; Di Lella, S.; Estrin, D.A.; Martí, M.A.; Moreno, D.M.; Nadra, A.D.; Petruk, A.A. Protein dynamics and ligand migration interplay as studied by computer simulation. Biochim. Biophys. Acta 2011, 1814, 1054-1064. [CrossRef]

38. De Simone, G.; di Masi, A.; Fattibene, P.; Ciaccio, C.; Platas-Iglesias, C.; Coletta, M.; Pesce, A.; Ascenzi, P. Oxygen-mediated oxidation of ferrous nitrosylated Nitrobindins. J. Inorg. Biochem. 2021, 224, 111579-111588. [CrossRef]

39. Karplus, M.; Petsko, G.A. Molecular dynamics simulations in biology. Nature 1990, 347, 631-639. [CrossRef] [PubMed]

40. Cui, Q.; Karplus, M. Allostery and cooperativity revisited. Protein Sci. 2008, 17, 1295-1307. [CrossRef]

41. Elber, R. Ligand diffusion in globins: Simulations versus experiment. Curr. Opin. Struct. Biol. 2010, 20, 162-167. [CrossRef] [PubMed]

42. Wei, X.; Yu, Z.; Cho, K.-S.; Chen, H.; Malik, M.T.A.; Chen, X.; Lo, E.H.; Wang, X.; Chen, D.F. Neuroglobin is an endogenous neuroprotectant for retinal ganglion cells against glaucomatous damage. Am. J. Pathol. 2011, 179, 2788-2797. [CrossRef] [PubMed]

43. Lechauve, C.; Augustin, S.; Cwerman-Thibault, H.; Bouaita, A.; Forster, V.; Célier, C.; Rustin, P.; Marden, M.C.; Sahel, J.-A.; Corral-Debrinski, M. Neuroglobin involvement in respiratory chain function and retinal ganglion cell integrity. Biochim. Biophys. Acta 2012, 1823, 2261-2273. [CrossRef] 
44. Ascenzi, P.; di Masi, A.; Leboffe, L.; Fiocchetti, M.; Nuzzo, M.T.; Brunori, M.; Marino, M. Neuroglobin: From structure to function in health and disease. Mol. Aspects Med. 2016, 52,1-48. [CrossRef] [PubMed]

45. Fiocchetti, M.; Cipolletti, M.; Marino, M. Compensatory role of neuroglobin in nervous and non-nervous cancer cells in response to the nutrient deprivation. PLoS ONE 2017, 12, e0189179. [CrossRef]

46. Fiocchetti, M.; Fernandez, V.S.; Montalesi, E.; Marino, M. Neuroglobin: A novel player in the oxidative stress response of cancer cells. Oxid. Med. Cell. Longev. 2019, 2019, 6315034. [CrossRef]

47. Van Acker, Z.P.; Van Raemdonck, G.A.; Logie, E.; Van Acker, S.I.; Baggerman, G.; Van den Berghe, W.; Ponsaerts, P.; Dewilde, S. Connecting the dots in the neuroglobin-protein interaction network of an unstressed and ferroptotic cell death neuroblastoma model. Cells 2019, 8, 873. [CrossRef]

48. Fiocchetti, M.; Cracco, P.; Montalesi, E.; Solar Fernandez, V.; Stuart, J.A.; Marino, M. Neuroglobin and mitochondria: The impact on neurodegenerative diseases. Arch. Biochem. Biophys. 2021, 701, 10882-108831. [CrossRef] [PubMed]

49. Gorabi, A.M.; Aslani, S.; Barreto, G.E.; Báez-Jurado, E.; Kiaie, N.; Jamialahmadi, T.; Sahebkar, A. The potential of mitochondrial modulation by neuroglobin in treatment of neurological disorders. Free Radic. Biol. Med. 2021, 162, 471-477. [CrossRef] [PubMed]

50. Lechauve, C.; Jager, M.; Laguerre, L.; Kiger, L.; Correc, G.; Leroux, C.; Vinogradov, S.; Czjzek, M.; Marden, M.C.; Bailly, X. Neuroglobins, pivotal proteins associated with emerging neural systems and precursors of metazoan globin diversity. J. Biol. Chem. 2013, 288, 6957-6967. [CrossRef]

51. Bashford, D.; Chothia, C.; Lesk, A.M. Determinants of a protein fold. Unique features of the globin amino acid sequences. J. Mol. Biol. 1987, 196, 199-216. [CrossRef]

52. Du, W.; Syvitski, R.; Dewilde, S.; Moens, L.; La Mar, G.N. Solution ${ }^{1} \mathrm{H}$ NMR characterization of equilibrium heme orientational disorder with functional consequences in mouse neuroglobin. J. Am. Chem. Soc. 2003, 125, 8080-8081. [CrossRef]

53. Guimarães, B.G.; Hamdane, D.; Lechauve, C.; Marden, M.C.; Golinelli-Pimpaneau, B. The crystal structure of wild-type human brain neuroglobin reveals flexibility of the disulfide bond that regulates oxygen affinity. Acta Crystallogr. D. Biol. Crystallogr. 2014, 70, 1005-1014. [CrossRef]

54. Walker, F.A. The heme environment of mouse Neuroglobin: Histidine imidazole plane orientations obtained from solution NMR and EPR spectroscopy as compared with X-ray crystallography. J. Biol. Inorg. Chem. 2006, 11, 391-397. [CrossRef]

55. Perutz, M.F. Myoglobin and haemoglobin: Role of distal residues in reactions with haem ligands. Trends Biochem. Sci. 1989, 14, 42-44. [CrossRef]

56. Brancaccio, A.; Cutruzzola, F.; Allocatelli, C.T.; Brunori, M.; Smerdon, S.J.; Wilkinson, A.J.; Dou, Y.; Keenan, D.; Ikeda-Saito, M.; Brantley, R.E., Jr.; et al. Structural factors governing azide and cyanide binding to mammalian metmyoglobins. J. Biol. Chem. 1994, 269, 13843-13853. [CrossRef]

57. Draghi, F.; Miele, A.E.; Travaglini-Allocatelli, C.; Vallone, B.; Brunori, M.; Gibson, Q.H.; Olson, J.S. Controlling ligand binding in myoglobin by mutagenesis. J. Biol. Chem. 2002, 277, 7509-7519. [CrossRef] [PubMed]

58. Moschetti, T.; Mueller, U.; Schulze, J.; Brunori, M.; Vallone, B. The structure of neuroglobin at high Xe and Kr pressure reveals partial conservation of globin internal cavities. Biophys. J. 2009, 97, 1700-1708. [CrossRef]

59. Abraini, J.H.; Marassio, G.; David, H.N.; Vallone, B.; Prangé, T.; Colloc'h, N. Crystallographic studies with xenon and nitrous oxide provide evidence for protein-dependent processes in the mechanisms of general anesthesia. Anesthesiology 2014, 121, 1018-1027. [CrossRef] [PubMed]

60. Avella, G.; Ardiccioni, C.; Scaglione, A.; Moschetti, T.; Rondinelli, C.; Montemiglio, L.C.; Savino, C.; Giuffrè, A.; Brunori, M.; Vallone, B. Engineering the internal cavity of Neuroglobin demonstrates the role of haem-sliding mechanism. Acta Crystallogr. Sect. D Biol. Crystallogr. 2014, 70, 1640-1648. [CrossRef]

61. Anselmi, M.; Brunori, M.; Vallone, B.; Di Nola, A. Molecular dynamics simulation of deoxy and carboxy murine Neuroglobin in water. Biophys. J. 2007, 93, 434-441. [CrossRef] [PubMed]

62. Anselmi, M.; Brunori, M.; Vallone, B.; Di Nola, A. Molecular dynamics simulation of the neuroglobin crystal: Comparison with the simulation in solution. Biophys. J. 2008, 95, 4157-4162. [CrossRef]

63. Lutz, S.; Nienhaus, K.; Nienhaus, G.U.; Meuwly, M. Ligand migration between internal docking sites in photodissociated carbonmonoxy Neuroglobin. J. Phys. Chem. B 2009, 113, 15334-15343. [CrossRef]

64. Nienhaus, K.; Lutz, S.; Meuwly, M.; Nienhaus, G.U. Structural identification of spectroscopic substates in neuroglobin. Chem. Phys. Chem. 2010, 11, 119-129. [CrossRef]

65. Anselmi, M.; Di Nola, A.; Amadei, A. Kinetics of carbon monoxide migration and binding in solvated Neuroglobin as revealed by molecular dynamics simulations and quantum mechanical calculations. J. Phys. Chem. B 2011, 115, 2436-2446. [CrossRef]

66. Nienhaus, K.; Lutz, S.; Meuwly, M.; Nienhaus, G.U. Reaction-pathway selection in the structural dynamics of a heme protein. Chemistry 2013, 19, 3558-3562. [CrossRef]

67. Lutz, S.; Meuwly, M. Structural characterization of spectroscopic substates in carbonmonoxy neuroglobin. Faraday Discuss. 2011, 150, 375-390. [CrossRef]

68. Stourac, J.; Vavra, O.; Kokkonen, P.; Filipovic, J.; Pinto, G.; Brezovsky, J.; Damborsky, J.; Bednar, D. Caver Web 1.0: Identification of tunnels and channels in proteins and analysis of ligand transport. Nucleic Acids Res. 2019, 47, W414-W422. [CrossRef] [PubMed]

69. Lilkova, E.; Petkov, P.; Ilieva, N.; Litov, L. The PyMOL molecular graphics system version 2.0, Software. Schrödinger LLC.: New York, NY, USA, 2015.

70. Brunori, M. Nitric oxide, cytochrome-c oxidase and myoglobin. Trends Biochem. Sci. 2001, 26, 21-23. [CrossRef] 
71. Schmidt, M.; Giessl, A.; Laufs, T.; Hankeln, T.; Wolfrum, U.; Burmester, T. How does the eye breathe? Evidence for neuroglobinmediated oxygen supply in the mammalian retina. J. Biol. Chem. 2003, 278, 1932-1935. [CrossRef] [PubMed]

72. Brunori, M.; Vallone, B. A globin for the brain. FASEB J. 2006, 20, 192-197. [CrossRef] [PubMed]

73. Ascenzi, P.; Gustincich, S.; Marino, M. Mammalian nerve globins in search of functions. IUBMB Life 2014, 66, 268-276. [CrossRef] [PubMed]

74. Hamdane, D.; Kiger, L.; Dewilde, S.; Green, B.N.; Pesce, A.; Uzan, J.; Burmester, T.; Hankeln, T.; Bolognesi, M.; Moens, L.; et al. The redox state of the cell regulates the ligand binding affinity of human neuroglobin and cytoglobin. J. Biol. Chem. 2003, 278, 51713-51721. [CrossRef]

75. Vinck, E.; Van Doorslaer, S.; Dewilde, S.; Moens, L. Structural change of the heme pocket due to disulfide bridge formation is significantly larger for neuroglobin than for cytoglobin. J. Am. Chem. Soc. 2004, 126, 4516-4517. [CrossRef]

76. Hamdane, D.; Kiger, L.; Hoa, G.H.B.; Dewilde, S.; Uzan, J.; Burmester, T.; Hankeln, T.; Moens, L.; Marden, M.C. High pressure enhances hexacoordination in neuroglobin and other globins. J. Biol. Chem. 2005, 280, 36809-36814. [CrossRef] [PubMed]

77. Jayaraman, T.; Tejero, J.; Chen, B.B.; Blood, A.B.; Frizzell, S.; Shapiro, C.; Tiso, M.; Hood, B.L.; Wang, X.; Zhao, X.; et al. 14-3-3 binding and phosphorylation of neuroglobin during hypoxia modulate six-to-five heme pocket coordination and rate of nitrite reduction to nitric oxide. J. Biol. Chem. 2011, 286, 42679-42689. [CrossRef] [PubMed]

78. Kiger, L.; Uzan, J.; Dewilde, S.; Burmester, T.; Hankeln, T.; Moens, L.; Hamdane, D.; Baudin-Creuza, V.; Marden, M.C. Neuroglobin ligand binding kinetics. IUBMB Life 2004, 56, 709-719. [CrossRef] [PubMed]

79. Brunori, M.; Giuffrè, A.; Nienhaus, K.; Nienhaus, G.U.; Scandurra, F.M.; Vallone, B. Neuroglobin, nitric oxide, and oxygen: Functional pathways and conformational changes. Proc. Natl. Acad. Sci. USA 2005, 102, 8483-8488. [CrossRef]

80. Giuffrè, A.; Moschetti, T.; Vallone, B.; Brunori, M. Neuroglobin: Enzymatic reduction and oxygen affinity. Biochem. Biophys. Res. Commun. 2008, 367, 893-898. [CrossRef] [PubMed]

81. De Sanctis, D.; Pesce, A.; Nardini, M.; Bolognesi, M.; Bocedi, A.; Ascenzi, P. Structure-function relationships in the growing hexa-coordinate hemoglobin sub-family. IUBMB Life 2004, 56, 643-651. [CrossRef]

82. Pesce, A.; De Sanctis, D.; Nardini, M.; Dewilde, S.; Moens, L.; Hankeln, T.; Burmester, T.; Ascenzi, P.; Bolognesi, M. Reversible hexa- to penta-coordination of the heme Fe atom modulates ligand binding properties of neuroglobin and cytoglobin. IUBMB Life 2004, 56, 657-664. [CrossRef]

83. Kakar, S.; Hoffman, F.G.; Storz, J.F.; Fabian, M.; Hargrove, M.S. Structure and reactivity of hexacoordinate hemoglobins. Biophys. Chem. 2010, 152, 1-14. [CrossRef] [PubMed]

84. Pettersen, E.F.; Goddard, T.D.; Huang, C.C.; Couch, G.S.; Greenblatt, D.M.; Meng, E.C.; Ferrin, T.E. UCSF Chimera-A visualization system for exploratory research and analysis. J. Comput. Chem. 2004, 25, 1605-1612. [CrossRef] [PubMed]

85. Dewilde, S.; Kiger, L.; Burmester, T.; Hankeln, T.; Baudin-Creuza, V.; Aerts, T.; Marden, M.C.; Caubergs, R.; Moens, L. Biochemical characterization and ligand binding properties of neuroglobin, a novel member of the globin family. J. Biol. Chem. 2001, 276, 38949-38955. [CrossRef] [PubMed]

86. Trent, J.T., III; Watts, R.A.; Hargrove, M.S. Human neuroglobin, a hexacoordinate hemoglobin that reversibly binds oxygen. J. Biol. Chem. 2001, 276, 30106-30110. [CrossRef]

87. Fago, A.; Mathews, A.J.; Dewilde, S.; Moens, L.; Brittain, T. The reactions of Neuroglobin with CO: Evidence for two forms of the ferrous protein. J. Inorg. Biochem. 2006, 100, 1339-1343. [CrossRef]

88. Smagghe, B.J.; Sarath, G.; Ross, E.; Hilbert, J.; Hargrove, M.S. Slow ligand binding kinetics dominate ferrous hexacoordinate hemoglobin reactivities and reveal differences between plants and other species. Biochemistry 2006, 45, 561-570. [CrossRef] [PubMed]

89. Vos, M.H.; Battistoni, A.; Lechauve, C.; Marden, M.C.; Kiger, L.; Desbois, A.; Pilet, E.; de Rosny, E.; Liebl, U. Ultrafast heme-residue bond formation in six-coordinate heme proteins: Implications for functional ligand exchange. Biochemistry 2008, 47, 5718-5723. [CrossRef]

90. Abbruzzetti, S.; Faggiano, S.; Bruno, S.; Spyrakis, F.; Mozzarelli, A.; Dewilde, S.; Moens, L.; Viappiani, C. Ligand migration through the internal hydrophobic cavities in human neuroglobin. Proc. Natl. Acad. Sci. USA 2009, 106, 18984-18989. [CrossRef] [PubMed]

91. Skommer, J.; Helbo, S.; Henty, K.; Brittain, T. Ligand binding, reactivity and biological activity of a distal pocket mutant of neuroglobin. Int. J. Biol. Macromol. 2012, 51, 284-290. [CrossRef]

92. Herold, S.; Fago, A.; Weber, R.E.; Dewilde, S.; Moens, L. Reactivity studies of the Fe(III) and Fe(II)NO forms of human neuroglobin reveal a potential role against oxidative stress. J. Biol. Chem. 2004, 279, 22841-22847. [CrossRef] [PubMed]

93. Bocahut, A.; Derrien, V.; Bernad, S.; Sebban, P.; Sacquin-Mora, S.; Guittet, E.; Lescop, E. Heme orientation modulates histidine dissociation and ligand binding kinetics in the hexacoordinated human neuroglobin. J. Biol. Inorg. Chem. 2013, 18, 111-122. [CrossRef] [PubMed]

94. Danielsson, J.; Meuwly, M. Atomistic simulation of adiabatic reactive processes based on multi-state potential energy surfaces. J. Chem. Theory Comput. 2008, 4, 1083-1093. [CrossRef] [PubMed]

95. Trashin, S.; de Jong, M.; Luyckx, E.; Dewilde, S.; De Wael, K. Electrochemical evidence for neuroglobin activity on NO at physiological concentrations. J. Biol. Chem. 2016, 291, 18959-18966. [CrossRef] [PubMed] 
96. Ascenzi, P.; Giacometti, G.M.; Antonini, E.; Rotilio, G.; Brunori, M. Equilibrium and kinetic evidence for a transition between six- and five-coordinate ferrous heme in the nitric oxide derivative of Aplysia myoglobin. J. Biol. Chem. 1981, 256, 5383-5386. [CrossRef]

97. Giacometti, G.M.; Ascenzi, P.; Bolognesi, M.; Brunori, M. Reactivity of ferric Aplysia myoglobin towards anionic ligands in the acidic region. Proposal for a structural model. J. Mol. Biol. 1981, 146, 363-374. [CrossRef]

98. Orlowski, S.; Nowak, W. Topology and thermodynamics of gaseous ligands diffusion paths in human neuroglobin. Biosystems 2008, 94, 263-266. [CrossRef] [PubMed]

99. Bocahut, A.; Bernad, S.; Sebban, P.; Sacquin-Mora, S. Relating the diffusion of small ligands in human Neuroglobin to its structural and mechanical properties. J. Phys. Chem. B 2009, 113, 16257-16267. [CrossRef] [PubMed]

100. Capece, L.; Marti, M.A.; Bidon-Chanal, A.; Nadra, A.; Luque, F.J.; Estrin, D.A. High pressure reveals structural determinants for globin hexacoordination: Neuroglobin and myoglobin cases. Proteins 2009, 75, 885-894. [CrossRef]

101. Astudillo, L.; Bernad, S.; Derrien, V.; Sebban, P.; Miksovska, J. Probing the role of the internal disulfide bond in regulating conformational dynamics in neuroglobin. Biophys. J. 2010, 99, L16-L18. [CrossRef] [PubMed]

102. Bocahut, A.; Bernad, S.; Sebban, P.; Sacquin-Mora, S. Frontier residues lining globin internal cavities present specific mechanical properties. J. Am. Chem. Soc. 2011, 133, 8753-8761. [CrossRef]

103. Yang, Y.; Allemand, F.; Guca, E.; Vallone, B.; Delbecq, S.; Roumestand, C. ${ }^{1} \mathrm{H},{ }^{15} \mathrm{~N}$ and ${ }^{13} \mathrm{C}$ backbone resonance assignments of murine met-neuroglobin, free and in complex with cyanide. Biomol. NMR Assign. 2015, 9, 153-156. [CrossRef]

104. Andreone, B.J.; Lacoste, B.; Gu, C. Neuronal and vascular interactions. Annu. Rev. Neurosci. 2015, 38, 25-46. [CrossRef]

105. McBryde, F.D.; Malpas, S.C.; Paton, J.F. Intracranial mechanisms for preserving brain blood flow in health and disease. Acta Physiol. 2017, 219, 274-287. [CrossRef]

106. Dienel, G.A. Brain glucose metabolism: Integration of energetics with function. Physiol. Rev. 2019, 99, 949-1045. [CrossRef]

107. Tang, B.L. Glucose, glycolysis, and neurodegenerative diseases. J. Cell. Physiol. 2020, 235, 7653-7662. [CrossRef]

108. Fago, A.; Hundahl, C.; Malte, H.; Weber, R.E. Functional properties of neuroglobin and cytoglobin. Insights into the ancestral physiological roles of globins. IUBMB Life 2001, 56, 689-696; Erratum in IUBMB Life 2005, 57, 461. [CrossRef]

109. Fago, A.; Hundahl, C.; Dewilde, S.; Gilany, K.; Moens, L.; Weber, R.E. Allosteric regulation and temperature dependence of oxygen binding in human neuroglobin and cytoglobin: Molecular mechanisms and physiological significance. J. Biol. Chem. 2004, 279, 44417-44426. [CrossRef]

110. Uzan, J.; Dewilde, S.; Burmester, T.; Hankeln, T.; Moens, L.; Hamdane, D.; Marden, M.C.; Kiger, L. Neuroglobin and other hexacoordinated hemoglobins show a weak temperature dependence of oxygen binding. Biophys. J. 2004, 87, 1196-1204. [CrossRef] [PubMed]

111. Hundahl, C.; Fago, A.; Dewilde, S.; Moens, L.; Hankeln, T.; Burmester Weber, R.E. Oxygen binding properties of non-mammalian nerve globins. FEBS J. 2006, 273, 1323-1329. [CrossRef]

112. Hundahl, C.; Kelsen, J.; Kjaer, K.; Rønn, L.C.B.; Weber, R.E.; Geuens, E.; Hay-Schmidt, A.; Nyengaard, A.J.R. Does neuroglobin protect neurons from ischemic insult? A quantitative investigation of neuroglobin expression following transient MCA in spontaneously hypertensive rats. Brain Res. 2006, 1085, 19-27. [CrossRef] [PubMed]

113. Van Doorslaer, S.; Dewilde, S.; Kiger, L.; Nistor, S.V.; Goovaerts, E.; Marden, M.C.; Moens, L. Nitric oxide binding properties of neuroglobin: A characterization by EPR and flash photolysis. J. Biol. Chem. 2003, 278, 4919-4925. [CrossRef]

114. Nienhaus, K.; Kriegl, J.M.; Nienhaus, G.U. Structural dynamics in the active site of murine neuroglobin and its effects on ligand binding. J. Biol. Chem. 2004, 279, 22944-22952. [CrossRef] [PubMed]

115. Džoljić, E.; Grbatinić, I.; Kostić, V. Why is nitric oxide important for our brain? Funct. Neurol. 2015, 30, 159-163. [CrossRef]

116. Garry, P.S.; Ezra, M.; Rowland, M.J.; Westbrook, J.; Pattinson, K.T.S. The role of the nitric oxide pathway in brain injury and its treatment-From bench to bedside. Exp. Neurol. 2015, 263, 235-243. [CrossRef]

117. Jin, K.; Mao, X.O.; Xie, L.; Khan, A.A.; Greenberg, D.A. Neuroglobin protects against nitric oxide toxicity. Neurosci. Lett. 2008, 430, 135-137. [CrossRef] [PubMed]

118. Smagghe, B.J.; Trent, J.T., 3rd; Hargrove, M.S. NO dioxygenase activity in hemoglobins is ubiquitous in vitro but limited by reduction in vivo. PLoS ONE 2008, 30, e2039. [CrossRef] [PubMed]

119. Tiso, M.; Tejero, J.; Basu, S.; Azarov, I.; Wang, X.; Simplaceanu, V.; Frizzell, S.; Jayaraman, T.; Geary, L.; Shapiro, C.; et al. Human neuroglobin functions as a redox-regulated nitrite reductase. J. Biol. Chem. 2011, 286, 18277-18289. [CrossRef] [PubMed]

120. Tejero, J.; Sparacino-Watkins, C.E.; Ragireddy, V.; Frizzell, S.; Gladwin, M.T. Exploring the mechanisms of the reductase activity of neuroglobin by site-directed mutagenesis of the heme distal pocket. Biochemistry 2015, 54, 722-733; Erratum in Biochemistry 2015, 54, 3716. [CrossRef] [PubMed]

121. Petersen, M.G.; Dewilde, S.; Fago, A. Reactions of ferrous neuroglobin and cytoglobin with nitrite under anaerobic conditions. J. Inorg. Biochem. 2008, 102, 1777-1782. [CrossRef] [PubMed]

122. Sturms, R.; DiSpirito, A.A.; Fulton, D.B.; Hargrove, M.S. Hydroxylamine reduction to ammonium by plant and cyanobacterial hemoglobins. Biochemistry 2011, 50, 10829-10835. [CrossRef]

123. Athwal, N.S.; Alagurajan, J.; Andreotti, A.H.; Hargrove, M.S. Role of reversible histidine coordination in hydroxylamine reduction by plant hemoglobins (Phytoglobins). Biochemistry 2016, 55, 5809-5817. [CrossRef] [PubMed]

124. Alagurajan, J.; Singh Athwal, N.; Hargrove, M.S. Steady-state kinetics of phytoglobin-catalyzed reduction of hydroxylamine to ammonium. Biochemistry 2018, 57, 4824-4832. [CrossRef] [PubMed] 
125. Gardner, P.R.; Gardner, D.P.; Gardner, A.P. Globins scavenge sulfur trioxide anion radical. J. Biol. Chem. 2015, 290, $27204-27214$. [CrossRef] [PubMed]

126. Sen, N. Functional and molecular insights of hydrogen sulfide signaling and protein sulfhydration. J. Mol. Biol. 2017, 429, 543-561. [CrossRef] [PubMed]

127. Kimura, $\mathrm{H}$. Hydrogen Sulfide $\left(\mathrm{H}_{2} \mathrm{~S}\right)$ and polysulfide $\left(\mathrm{H}_{2} \mathrm{~S}_{\mathrm{n}}\right)$ signaling: The first 25 years. Biomolecules 2021, 11, 896. [CrossRef]

128. Rizzi, M.; Wittenberg, J.B.; Coda, A.; Fasano, M.; Ascenzi, P.; Bolognesi, M. Structure of the sulfide-reactive hemoglobin from the clam Lucina pectinata. Crystallographic analysis at $1.5 \AA$ A resolution. J. Mol. Biol. 1994, 244, 86-99. [CrossRef] [PubMed]

129. Rizzi, M.; Wittenberg, J.B.; Coda, A.; Ascenzi, P.; Bolognesi, M. Structural bases for sulfide recognition in Lucina pectinata hemoglobin I. J. Mol. Biol. 1996, 258, 1-5. [CrossRef]

130. Brittain, T.; Yosaatmadja, Y.; Henty, K. The interaction of human neuroglobin with hydrogen sulphide. IUBMB Life 2008, 60, 135-138. [CrossRef]

131. Ruetz, M.; Kumutima, J.; Lewis, B.E.; Filipovic, M.R.; Lehnert, N.; Stemmler, T.L.; Banerjee, R. A distal ligand mutes the interaction of hydrogen sulfide with human neuroglobin. J. Biol. Chem. 2017, 292, 6512-6528. [CrossRef]

132. Yamashita, T.; Hafsi, L.; Masuda, E.; Tsujino, H.; Uno, T. Ferric human neuroglobin scavenges superoxide to form oxy adduct. Chem. Pharm. Bull. 2014, 62, 613-615. [CrossRef] [PubMed]

133. Ezhevskaya, M.; Trandafir, F.; Moens, L.; Dewilde, S.; Van Doorslaer, S. EPR investigation of the role of B10 phenylalanine in neuroglobin: Evidence that B10Phe mediates structural changes in the heme region upon disulfide-bridge formation. J. Inorg. Biochem. 2011, 105, 1131-1137. [CrossRef]

134. Li, W.; Wu, Y.; Ren, C.; Lu, Y.; Gao, Y.; Zheng, X.; Zhang, C. The activity of recombinant human neuroglobin as an antioxidant and free radical scavenger. Proteins 2011, 79, 115-125. [CrossRef]

135. Sacksteder, C.A.; Qian, W.-J.; Knyushko, T.V.; Wang, H.; Chin, M.H.; Lacan, G.; Melega, W.P.; Camp, D.G., II; Smith, R.D.; Smith, D.J.; et al. Endogenously nitrated proteins in mouse brain: Links to neurodegenerative diseases. Biochemistry 2006, 45, 8009-8022. [CrossRef]

136. Nicolis, S.; Monzani, E.; Ciaccio, C.; Ascenzi, P.; Moens, L.; Casella, L. Reactivity and endogenous modification by nitrite and hydrogen peroxide: Does human neuroglobin act only as a scavenger? Biochem. J. 2007, 407, 89-99. [CrossRef] [PubMed]

137. Fordel, E.; Thijs, L.; Martinet, W.; Lenjou, M.; Laufs, T.; Van Bockstaele, D.; Moens, L.; Dewilde, S. Neuroglobin and Cytoglobin overexpression protects human SH-SY5Y neuroblastoma cells against oxidative stress-induced cell death. Neurosci. Lett. 2006, 410, 146-151. [CrossRef] [PubMed]

138. Li, Y.; Dai, Y.; Sun, J.; Xiang, Y.; Yang, J.; Dai, S.; Zhang, X. Neuroglobin attenuates beta amyloid-induced apoptosis through inhibiting caspases activity by activating PI3K/Akt signaling pathway. J. Mol. Neurosci. 2016, 58, 28-38. [CrossRef] [PubMed]

139. Yu, Z.; Cheng, C.; Liu, Y.; Liu, N.; Lo, E.H.; Wang, X. Neuroglobin promotes neurogenesis through Wnt signaling pathway. Cell Death Dis. 2018, 9, 945-956. [CrossRef]

140. De Vidania, S.; Palomares-Perz, I.; Frank-Garcia, A.; Saito, T.; Saido, T.C.; Draffin, J.; Szaruga, M.; Chavez-Gutierrez, L.; Calero, M.; Medina, M.; et al. Prodromal Alzheimer's disease: Constitutive upregulation of Neuroglobin prevents the initiation of Alzheimer's pathology. Front. Neurosci. 2020, 14, 562581-562598. [CrossRef] [PubMed]

141. Lechauve, C.; Augustin, S.; Roussel, D.; Sahel, J.-A.; Corral-Debrinski, M. Neuroglobin involvement in visual pathways through the optic nerve. Bochim. Biophys. Acta 2013, 1834, 1772-1778. [CrossRef]

142. Moschetti, T.; Giuffrè, A.; Ardiccioni, C.; Vallone, B.; Modjtahedi, N.; Kroemer, G.; Brunori, M. Failure of apoptosis-inducing factor to act as neuroglobin reductase. Biochem. Biophys. Res. Commun. 2009, 390, 121-124. [CrossRef] [PubMed]

143. Cwerman-Thibault, H.; Lechauve, C.; Augustin, S.; Roussel, D.; Reboussin, E.; Mohammad, A.; Degardin-Chicaud, J.; Simonutti, M.; Liang, H.; Brignole-Baudouin, F.; et al. Neuroglobin can prevent or reverse glaucomatous progression in DBA/2J mice. Mol. Ther. Meth. Clin. Dev. 2017, 5, 200-220. [CrossRef] [PubMed]

144. Roberts, P.A.; Gaffney, E.A.; Luthert, P.J.; Foss, A.J.E.; Byrne, H.M. Retinal oxygen distribution and the role of neuroglobin. J. Math. Biol. 2016, 73, 1179-1204. [CrossRef]

145. Shi, S.-Y.; Feng, X.-M.; Li, Y.; Li, X.; Chen, X.-L. Expression of neuroglobin in ocular hypertension induced acute hypoxic-ischemic retinal injury in rats. Int. J. Ophthalmol. 2011, 4, 393-395. [CrossRef] [PubMed]

146. Sun, Y.; Jin, K.; Mao, X.O.; Zhu, Y.; Greenberg, D.A. Neuroglobin is up-regulated by and protects neurons from hypoxic-ischemic injury. Proc. Natl. Acad. Sci. USA 2001, 98, 15306-15311. [CrossRef]

147. Sun, Y.; Jin, K.; Peel, A.; Mao, X.O.; Xie, L.; Greenberg, D.A. Neuroglobin protects the brain from experimental stroke in vivo. Proc. Natl. Acad. Sci. USA 2003, 100, 3497-3500. [CrossRef] [PubMed]

148. Khan, A.A.; Wang, Y.; Sun, Y.; Mao, X.O.; Xie, L.; Miles, E.; Graboski, J.; Chen, S.; Ellerby, L.M.; Jin, K.; et al. Neuroglobinoverexpressing transgenic mice aare resistant to cerebral and myocardial ischemia. Proc. Natl. Acad. Sci. USA 2006, 103, 17944-17948. [CrossRef] [PubMed]

149. Raida, Z.; Hundahl, C.A.; Nyengaard, J.R.; Hay-Schmidt, A. Neuroglobin over expressing mice: Expression pattern and effect on brain ischemic infarct size. PLoS ONE 2013, 8, e76565. [CrossRef]

150. Tun, S.B.B.; Barathi, V.A.; Luu, C.D.; Lynn, M.N.; Chan, A.S.Y. Effects of exogenous neuroglobin (Ngb) on retinal inflammatory chemokines and microglia in a rat model of transient hypoxia. Sci. Rep. 2019, 9, 18799-18885. [CrossRef]

151. Xu, Y.; Li, Z.; Tang, Y.; Yang, M.; Long, S.; Shu, P.; Li, J.; Xiao, Y.; Tang, F.; Wei, C.; et al. Neuroglobin regulates Wnt/ $\beta$-catenin and NFkB signaling pathway through Dvl1. Int. J. Mol. Sci. 2018, 19, 2133. [CrossRef] 
152. Chan, A.S.Y.; Saraswathy, S.; Rehak, M.; Ueki, M.; Rao, N.A. Neuroglobin protection in retinal ischemia. Invest. Ophtalmol. Visual. Sci. 2012, 53, 704-711. [CrossRef]

153. Singh, S.; Zhuo, M.; Gorgun, F.M.; Englander, E.W. Overexpressed neuroglobin raises threshold for nitric oxide-induced impairment of mitochondrial respiratory activities and stress signaling in primary cortical neurons. Nitric Oxide 2013, 32, 21-28. [CrossRef] [PubMed]

154. Yu, Z.; Liu, N.; Li, Y.; Xu, J.; Wang, X. Neuroglobin overexpression inhibits oxygen-glucose deprivation-induced mitochondrial permeability transition pore opening in primary cultured mouse cortical neurons. Neurobiol. Dis. 2013, 56, 95-103. [CrossRef] [PubMed]

155. Della Valle, B.; Hempel, C.; Kurtzhals, J.A.; Penkowa, M. In vivo expression of neuroglobin in reactive astrocytes during neuropathology in murine models of traumatic brain injury, cerebral malaria, and autoimmune encephalitis. Glia 2010, 58, 1220-1227. [CrossRef] [PubMed]

156. Lima, D.C.; Cossa, A.C.; Perosa, S.R.; de Oliveira, E.M.; da Silva, J.A., Jr.; da Silva Fernandes, M.J.; da Silva, I.R.; Higa, E.M.; da Graça Naffah-Mazzacoratti, M.; Cavalheiro, E.A.; et al. Neuroglobin is up-regulated in the cerebellum of pups exposed to maternal epileptic seizures. Int. J. Dev. Neurosci. 2011, 29, 891-897. [CrossRef] [PubMed]

157. Yu, Z.-L.; Qiu, S.; Chen, X.-C.; Dai, Z.-H.; Huang, Y.-C.; Li, Y.-N.; Cai, R.-H.; Lei, H.-T.; Gu, H.-Y. Neuroglobin-A potential biological marker of retinal damage induced by led light. Neuroscience 2014, 270, 158-167. [CrossRef]

158. Sugitani, K.; Koriyama, Y.; Sera, M.; Arai, K.; Ogai, K.; Wakasugi, K. A novel function of neuroglobin for neurodegeneration in mice after optic nerve injury. Biochem. Biophys. Res. Comm. 2017, 493, 1254-1259. [CrossRef]

159. Kamioka, Y.; Fujikawa, C.; Ogai, K.; Sugitani, K.; Watanabe, S.; Kato, S.; Wakasugi, K. Functional characterization of fish neuroglobin: Zebrafish neuroglobin is highly expressed in amacrine cells after optic nerve injury and can translocate into ZF4 cells. Biochim. Biophys. Acta 2013, 1834, 1779-1788. [CrossRef]

160. Bønding, S.H.; Henty, K.; Dingley, A.J.; Brittain, T. The binding of cytochrome $c$ to neuroglobin: A docking and surface plasmon resonance study. Int. J. Biol. Macromol. 2008, 43, 295-299. [CrossRef] [PubMed]

161. De Marinis, E.; Fiocchetti, M.; Acconcia, F.; Ascenzi, P.; Marino, M. Neuroglobin upregulation induced by $17 \beta$-estradiol sequesters cytocrome $\mathrm{c}$ in the mitochondria preventing $\mathrm{H}_{2} \mathrm{O}_{2}$-induced apoptosis of neuroblastoma cells. Cell Death Dis. 2013, 4, e508. [CrossRef]

162. Raychaudhuri, S.; Skommer, J.; Henty, K.; Birch, N.; Brittain, T. Neuroglobin protects nerve cells from apoptosis by inhibiting the intrinsic pathway of cell death. Apoptosis 2010, 15, 401-411. [CrossRef]

163. Tejero, J. Negative surface charges in neuroglobin modulate the interaction with cytochrome c. Biochem. Biophys. Res. Comm. 2020 523, 567-572. [CrossRef] [PubMed]

164. Schmidt-Kastner, R.; Haberkamp, M.; Schmitz, C.; Hankeln, T.; Burmester, T. Neuroglobin mRNA expression after transient global brain ischemia and prolonged hypoxia in cell culture. Brain Res. 2006, 1103, 173-180. [CrossRef]

165. Kelsen, J.; Hundahl, C.A.; Hay-Schmidt, A. Neuroglobin: Endogenous neuroprotectant or maintenance of homeostasis? Stroke 2008, 39, e177-e178. [CrossRef]

166. Raida, Z.; Hundahl, C.A.; Kelsen, J.; Nyengaard, J.R.; Hay-Schmidt, A. Reduced infarct size in neuroglobin-null mice after experimental stroke in vivo. Exp. Transl. Stroke Med. 2012, 4, 15-16. [CrossRef]

167. Di Pietro, V.; Lazzarino, G.; Amorini, A.M.; Tavazzi, B.; D’Urso, S.; Longo, S.; Vagnozzi, R.; Signoretti, S.; Clementi, E.; Giardina, B.; et al. Neuroglobin expression and oxidant/antioxidant balance after graded traumatic brain injury in the rat. Free Radic. Biol. Med. 2014, 69, 258-264. [CrossRef] [PubMed]

168. Fabrizius, A.; Andre, D.; Laufs, T.; Bicker, A.; Reuss, S.; Porto, E.; Burmester, T.; Hankeln, T. Critical re-evaluation of neuroglobin expression reveals conserved patterns among mammals. Neuroscience 2016, 337, 339-354. [CrossRef] [PubMed]

169. Hundahl, C.A.; Fahrenkrug, J.; Luuk, H.; Hay-Schmidt, A.; Hannibal, J. Restricted expression of neuroglobin in the mouse retina and co-localization with melanopsin and tyrosine hydroxylase. Biochem. Biophys. Res. Commun. 2012, 425, 100-106. [CrossRef]

170. Cai, B.; Lin, Y.; Xue, X.H.; Fang, L.; Wang, N.; Wu, Z.Y. TAT-mediated delivery of neuroglobin protects against focal cerebral ischemia in mice. Exp. Neurol. 2011, 227, 224-231. [CrossRef]

171. Khan, A.A.; Mao, X.O.; Banwait, S.; DerMardirossian, C.M.; Bokoch, G.M.; Jin, K.; Greenberg, D.A. Regulation of hypoxic neuronal death signaling by neuroglobin. FASEB J. 2008, 22, 1737-1747. [CrossRef] [PubMed]

172. Solar Fernandez, V.; Fiocchetti, M.; Cipolletti, M.; Segatto, M.; Cercola, P.; Massari, A.; Ghinassi, S.; Cavaliere, F.; Marino, M. Neuroglobin: A new possible marker of estrogen-responsive breast cancer. Cells 2021, 10, 1986. [CrossRef] [PubMed]

173. Khan, A.A.; Sun, Y.; Jin, K.; Mao, X.O.; Chen, S.; Ellerby, L.M.; Greenberg, D.A. A neuroglobin-overexpressing transgenic mouse. Gene 2007, 398, 172-176. [CrossRef] [PubMed]

174. Lechauve, C.; Augustin, S.; Cwerman-Thibault, H.; Reboussin, E.; Roussel, D.; Lai-Kuen, R.; Saubamea, B.; Sahel, J.-A.; Debeir, T.; Corral-Debrinski, M. Neuroglobin gene therapy prevents optic atrophy and preserves durably visual function in Harlequin mice. Mol. Ther. 2014, 22, 1096-1109. [CrossRef] [PubMed] 